\title{
Salinity effects on cultured Neogloboquadrina pachyderma (sinistral) from high latitudes: new paleoenvironmental insights
}

\author{
Jacqueline Bertlich ${ }^{1,2}$ (D) $\cdot$ Nikolaus Gussone ${ }^{1,3} \cdot$ Jasper Berndt $^{1} \cdot$ Heinrich F. Arlinghaus ${ }^{4} \cdot$ Gerhard S. Dieckmann $^{5}$
}

Received: 17 June 2020 / Accepted: 4 December 2020 / Published online: 5 January 2021

(C) The Author(s) 2020

\begin{abstract}
This study presents culture experiments of the cold water species Neogloboquadrina pachyderma (sinistral) and provides new insights into the incorporation of elements in foraminiferal calcite of common and newly established proxies for paleoenvironmental applications (shell $\mathrm{Mg} / \mathrm{Ca}, \mathrm{Sr} / \mathrm{Ca}$ and $\mathrm{Na} / \mathrm{Ca}$ ). Specimens were collected from sea ice during the austral winter in the Antarctic Weddell Sea and subsequently cultured at different salinities and a constant temperature. Incorporation of the fluorescent dye calcein showed new chamber formation in the culture at salinities of 30,31, and 69. Cultured foraminifers at salinities of 46 to 83 only revealed chamber wall thickening, indicated by the fluorescence of the whole shell. Signs of reproduction and the associated gametogenic calcite were not observed in any of the culture experiments. Trace element analyses were performed using an electron microprobe, which revealed increased shell $\mathrm{Mg} / \mathrm{Ca}, \mathrm{Sr} / \mathrm{Ca}$, and $\mathrm{Na} / \mathrm{Ca}$ values at higher salinities, with $\mathrm{Mg} / \mathrm{Ca}$ showing the lowest sensitivity to salinity changes. This study enhances the knowledge about unusually high element concentrations in foraminifera shells from high latitudes. Neogloboquadrina pachyderma appears to be able to calcify in the Antarctic sea ice within brine channels, which have low temperatures and exceptionally high salinities due to ongoing sea ice formation.
\end{abstract}

\section{Introduction}

In high latitudes, faunal assemblages are dominated by the polar non-spinose, symbiont-barren species Neogloboquadrina pachyderma (sinistral) (Tolderlund and Bé 1971; Spindler 1996; Meland et al. 2006; Hendry et al. 2009). This emphasizes the application of N. pachyderma (s) shells as an ideal proxy

\footnotetext{
Highlights Chamber formation of $N$. pachyderma (s) in cultures at salinities between 31 and 69, chamber wall thickening at $\mathrm{S} 83$.

Salinity affects incorporation of $\mathrm{Mg} / \mathrm{Ca}, \mathrm{Sr} / \mathrm{Ca}$, and $\mathrm{Na} / \mathrm{Ca}$ in N. pachyderma.

$N$. pachyderma grown in sea ice brine pockets at high salinities may alter the paleoenvironmental record.

Foraminifers retrieved from sea ice are able to calcify in laboratory cultures.
}

Jacqueline Bertlich

jbertlich@geomar.de

Nikolaus Gussone

nikolaus.gussone@uni-muenster.de

1 Institut für Mineralogie, Westfälische Wilhelms-Universität Münster, Corrensstraße 24, 48149 Münster, Germany

2 Present address: GEOMAR Helmholtz Centre for Ocean Research Kiel, Wischhofstr. 1-3, 24148 Kiel, Germany archive for paleoceanographic reconstructions in polar environments. The analysis of foraminiferal $\mathrm{Mg} / \mathrm{Ca}$ is a wellestablished approach to reconstruct past sea surface temperatures in tropical to mid-latitude regions (e.g., Nürnberg et al. 1996; Lea et al. 1999; Elderfield and Ganssen 2000; Anand et al. 2003; Gussone et al. 2004). Paleo-reconstructions in subpolar and polar regions are limited to a certain extent due to the

Present address: Wessling GmbH, Oststr. 7, 48341 Altenberge, Germany

4 Physikalisches Institut, Westfälische Wilhelms-Universität Münster, Wilhelm-Klemm-Str. 10, 48149 Münster, Germany

5 Marine Biogeosciences, Alfred-Wegener-Institut Helmholtz-Zentrum für Polar- und Meeresforschung, Am Handelshafen 12, 27570 Bremerhaven, Germany 
exponential $\mathrm{Mg} / \mathrm{Ca}$-temperature relation, causing a low temperature-sensitivity of foraminiferal $\mathrm{Mg} / \mathrm{Ca}$ values in cold water masses (e.g., Nürnberg 1995; Elderfield and Ganssen 2000; Meland et al. 2006).

However, earlier studies reported elevated $\mathrm{Mg} / \mathrm{Ca}$ values in N. pachyderma, collected from core-top sediments in Prydz Bay (Antarctica) and the Nordic Seas (Eggins et al. 2003; Meland et al. 2006). Such higher trace element values cannot solely be explained by temperature fluctuations, potentially influencing $\mathrm{Mg}$ incorporation. The former authors hypothesize that higher foraminiferal $\mathrm{Mg} / \mathrm{Ca}$ values are possibly correlated to changes in the seawater chemistry (e.g., salinity (S), carbonate ion concentration $\left[\mathrm{CO}_{3}{ }^{2-}\right], \mathrm{pH}$, alkalinity) due to the influence of changing water masses caused by sea ice cover. This hypothesis is still under discussion and needs further verification.

On this basis, our study presents new environmental insights of $N$. pachyderma (s) specimens from a polar environment - the Antarctic sea ice in the Weddell Sea. This study aims to clarify whether $N$. pachyderma (s) specimens are capable of secreting calcite shells under extreme temperature and salinity conditions within sea ice. If so, are there distinct geochemical changes in the proxy signatures of $N$. pachyderma (s) specimens cultured in high salinities that are characteristic of sea ice conditions and individuals cultured in lower salinities that reflect conditions in the pelagic ocean? This could potentially alter paleo-oceanographic reconstructions from sedimentary records. To answer these questions, we present culture experiments of living foraminifers collected from the Antarctic sea ice. Element concentrations of newly calcified chambers in culture were measured by electron microprobe analyses. We determined foraminiferal $\mathrm{Mg} / \mathrm{Ca}$, a well-established proxy to reconstruct paleo-temperatures, and foraminiferal $\mathrm{Sr} / \mathrm{Ca}$, which is assumed to be primarily controlled by changes in seawater $\mathrm{Sr} / \mathrm{Ca}$ (Elderfield et al. 2000; Gray and Evans 2019; Lea et al. 1999). We also measured shell $\mathrm{Na} / \mathrm{Ca}$, a newly introduced proxy to directly quantify sea surface salinities (Allen et al. 2016; Bertlich et al. 2018; Mezger et al. 2016; Wit et al. 2013). The direct relationship of foraminiferal $\mathrm{Na} / \mathrm{Ca}$ to seawater salinity is highly relevant for paleo-applications, as previous approaches are either regionally limited (e.g., shell $\mathrm{Ba} / \mathrm{Ca}$ ), or rely on combined temperature proxies (e.g., paired shell $\mathrm{Mg} / \mathrm{Ca}, \mathrm{TEX}_{86}$, and shell $\delta^{18} \mathrm{O}$ ) to estimate sea surface salinities indirectly and qualitatively (Elderfield and Ganssen 2000; Huguet et al. 2007; Rohling and Bigg 1998; Rosenthal et al. 2000; Schouten et al. 2002). Moreover, this study presents the first insights into the $\mathrm{Na} / \mathrm{Ca}$ to salinity relationship in symbiont-barren and cold-water species.

Our culture experiments are based on observations by Spindler and Dieckmann (1986), who determined that juveniles of $N$. pachyderma from surface waters are incorporated and enclosed into the sea ice during the yearly Antarctic sea ice formation in the Weddell Sea. Foraminifers continue to live in the remaining channels and pockets, filled with sea ice brine. During the winter season lower temperatures cause further sea ice formation (e.g., $\sim-2{ }^{\circ} \mathrm{C}$ to $-15{ }^{\circ} \mathrm{C}$ at the seawater/sea ice interface) while brine channels become even narrower (Bartsch 1989; Spindler 1996). The salt continuously accumulates in the fluid, which could lead to an increase in salinity up to $\sim 160-180$ in the brine pockets or channels. Therefore, salinity and temperature are inversely correlated in sea ice (Spindler 1996). It is likely that foraminiferal calcite formed in this environment may significantly impact the fossil record due to differences in the brine composition. Moreover, the abundances of $N$. pachyderma (s) are 70 times higher per liter ice in newly formed sea ice of the Weddell Sea than in the underlying water column (Spindler and Dieckmann 1986; Dieckmann et al. 1991; Bergami et al. 2009). Numerous living juvenile foraminifers and their empty shells $(\leq 80 \mu \mathrm{m})$ were observed in the upper parts of newly formed sea ice $(5-10 \mathrm{~cm}$ thick). Living foraminifers being at a later life stage $>200 \mu \mathrm{m}$ were most abundant in the lower, older, and thicker parts of sea ice $(\geq 1 \mathrm{~m})$ close to the seawater interface (Berberich 1996; Dieckmann et al. 1991; Spindler 1996; Spindler and Dieckmann 1986). The first indication for a potential growth of $N$. pachyderma (s) specimens trapped within sea ice was provided by Berberich (1996). While the lifecycle of $N$. pachyderma (s) in sea ice is not yet well constrained, the here presented culture experiments provide new insights into the salinity tolerance of $N$. pachyderma (s) and potential effects on shell geochemistry.

\section{Materials and methods}

\section{Environmental settings and culture experiments}

Foraminifers of the planktonic species Neogloboquadrina pachyderma (sinistral) were collected from the Antarctic sea ice of the Weddell Sea in the austral winter of 2013 during the expedition ANT-XXIX/6 of RV Polarstern. The cruise track and sampling sites along the Weddell Gyre are presented in Fig. 1. More details of the cruise track and sampling locations are provided in the cruise report (Lemke 2014a). Living foraminifers were collected for culture experiments at three sampling stations (PS81/497, 503, 506) from sea ice brines. These foraminifers formed their chambers (before being placed in culture) most likely in the pelagic ocean close to the sea surface/sea ice interface or in less evolved sea ice brines, as the onset of yearly sea ice formation just started at the time of sampling. Surface water salinities varied marginal (S $34.3 \pm$ 0.1 ) depending on the water depth (0 to $20 \mathrm{~m}$ ) and also with the sampling sites (Lemke 2014b; World Ocean Atlas 2013 (WOA2013): Zweng et al. 2013). Earlier studies reported sea ice brine salinities of S 34.2 to 34.4 at the water interface equal 




Fig. 1 Cruise track of the RV Polarstern expedition ANT-XXIX/6 and its respective sampling locations of sea ice derived foraminifers Neogloboquadrina pachyderma (sinistral) for onboard culture experiments. Dashed lines indicate the edge of sea ice cover at the time of

sampling (modified after Lemke 2014b). The map was created with Ocean Data View (Schlitzer 2015), and cruise track information was taken from the online database PANGEA (Lemke, 2014a)

to sea surface values in the austral spring/summer (Tison et al. 2008). Brine salinities could increase to $S 48$ with increasing sea ice thickness (60 cm; Tison et al. 2008; Berberich 1996), or up to values of S 63 observed at $\sim 1.80 \mathrm{~m}$ of sea ice thickness (Papadimitriou et al. 2007). This allows us to present the potential range of natural salinity in which foraminifers could have grown their chambers before being placed in culture. Living foraminifers were collected from sea ice close to the ice/water interface below a sampling depth of $<\sim 40 \mathrm{~cm}$. Therefore, salinity uncertainties of S 34-48 are taken into account, indicated by the horizontal error bars, when comparing preceding chambers $(\mathrm{F}-1, \mathrm{~F}-2)$ grown in the natural environment and final newly formed chambers, labeled as $\mathrm{F}$ for final, in culture.

To gently extract foraminifers from the sea ice, the respective ice cores were melted in filtered seawater at -1 to $-2{ }^{\circ} \mathrm{C}$ to avoid extreme temperature or salinity changes. The number of specimens per treatment varied in relation to the number of foraminifers in the specific sea ice samples. For culture experiments, foraminifers were kept in solutions with different salinities (S) varying from S 30 to S 83 (Table 1). The different salinities were obtained either from filtered natural sea ice brines, which were extracted via a drainage system by drilling so-called sackholes into the ice (Lemke 2014b), or from artificial brines, which were produced from partial freezing of filtered seawater. Subsequently, these solutions were used as culture media and therefore not further altered, explaining the uneven salinity values (Table 1). The salinities were determined using a calibrated WTW salinometer with a precision of $\sim \pm 0.1$ (Lemke 2014b). To identify newly formed calcite shells in culture, the organic fluorescent dye calcein $(\mathrm{Bis}[\mathrm{N}, \mathrm{N}$ bis(carboxymethyl)aminomethyl]-fluorescein) was added to each experimental setup. Calcein concentrations of the culture media were determined after the cruise at the Institut für 
Table 1 Overview of sampling stations, experimental settings, and the number of foraminifers that incorporated the fluorescent dye calcein during chamber calcification in culture. Salinity experiments are numbered from 1 to 10 . The temperature was kept between -1 and +2
${ }^{\circ} \mathrm{C}$ throughout all experiments. Experiments used for further trace element analysis, applying the electron microprobe technique, are shown in italic

\begin{tabular}{|c|c|c|c|c|c|c|}
\hline Sample station PS 81/ & $\begin{array}{l}\text { Culture } \\
\text { medium }\end{array}$ & Salinity & $\begin{array}{l}\text { Total number of } \\
\text { specimens \# }\end{array}$ & Calcein-labeled chamber F & $\begin{array}{l}\text { Whole shell } \\
\text { calcein- } \\
\text { labeled }\end{array}$ & Reddish* fluorescence \\
\hline 503 & Artificial brine & 46 & 3 & - & 3 & - \\
\hline 503 Bulk1 & Artificial brine & 83 & 17 & - & 10 & 4 \\
\hline 503 Bulk2 & Artificial brine & 63 & 2 & - & 2 & - \\
\hline $506 \mathrm{~g}-1$ & Artificial brine & 76 & 5 & - & 2 & - \\
\hline $506 \mathrm{~g}-2$ & Natural brine & 68 & 7 & - & - & 7 \\
\hline $506 \mathrm{~g}-3$ & Natural brine & 56 & 15 & - & - & 15 \\
\hline $506 \mathrm{~g}-4$ & Natural brine & 59 & 9 & - & 2 & - \\
\hline $506 \mathrm{~g}-5$ & Natural brine & 47 & 4 & - & - & - \\
\hline $506 \mathrm{~g}-6$ & Natural brine & 39 & 2 & - & - & - \\
\hline $506 g-7$ & Diluted brine & 31 & 10 & 5 & 2 & - \\
\hline $506 g-10$ & Natural brine & 69 & 317 & 95 & 5 & 16 \\
\hline $500($ GSD 64) & Melted ice core & 30 & 18 & 1 & - & 1 \\
\hline
\end{tabular}

*Reddish color indicates foraminifers displaying a red fluorescence throughout the shell, possibly indicating remains of organic matter (cf. Fig. 2b, h)

Mineralogie (Universität Münster) using a Perkin Elmer Lamda $10 \mathrm{UV} / \mathrm{VIS}$ photometer at a wavelength of $476.5 \mathrm{~nm}$ and ranged between 9.9 and $14.4 \mu \mathrm{mol} / \mathrm{L}$. Replicate analyses of samples showed a standard deviation (SD) of $0.2 \%$. In the culture media, calcein concentrations were rather low $(<20$ $\mathrm{mg} / \mathrm{l}$ ) and hence did not influence the viability of foraminifers or the geochemical shell signature markedly (Bernhard et al. 2004; Kurtarkar et al. 2015; Fox et al. 2018). Calcein was incorporated into cultured foraminifers and has been shown to cause fluorescence only in the newly calcified chambers and not in pre-existing parts (Dissard et al. 2009). The same study revealed that trace element incorporation in biologically and inorganically precipitated calcite is not influenced by the calcein dye. Individuals of $N$. pachyderma (sinistral) were kept for 12 weeks in the respective media and were fed with ice algae. The temperature was maintained during the experiments between -1 and $+2{ }^{\circ} \mathrm{C}$ (Table 1$)$.

\section{Cleaning protocol}

After termination of the culture experiments, foraminifers were separated from the culture medium by filtration with cellulose nitrate membrane filters $(0.45 \mu \mathrm{m}$ pore size $)$ and dried. Subsequently, shells of $N$. pachyderma (s) were cleaned following the method for $\mathrm{Mg} / \mathrm{Ca}, \mathrm{Sr} / \mathrm{Ca}$, and $\mathrm{U} / \mathrm{Ca}$ ratios of calcareous dinoflagellate cysts (Gussone et al. 2010; Gussone and Friedrich 2018). The foraminifers were cleaned with ultrapure water (Milli-Q) to wash out particles such as algae residues, attached salt and, calcein from the culture medium. The $\mathrm{pH}$ value of the ultra-pure water was buffered and adjusted to
9 by the addition of a $25 \%$ ammonia solution to avoid dissolution of the carbonate shells. Subsequently, the shells were bleached with sodium hypochlorite $(\mathrm{NaOCl})$ solution $(\sim 1.3 \%$ active chlorine) to gently remove the remnant cytoplasm. The samples were kept in the bleach for $24 \mathrm{~h}$ and were washed afterwards six times with ultra-pure water to remove the bleach. Finally, all cleaned foraminifers were dried to avoid partial dissolution. The extensive cleaning method for foraminifers from sediment cores after Barker et al. (2003) is not required since the culture experiments were implemented without sediment (Dissard et al. 2010).

\section{Analytical methods}

\section{Sample selection}

Individual foraminifers that formed new calcite during the culture experiments were identified by UV-light induced fluorescence using a light-optical microscope (Institut für Geologie und Paläontologie, Forschungsstelle für Paläobotanik, Universität Münster). These newly calcified chambers showed a yellow-greenish fluorescence (excitation of $470 \mathrm{~nm}$ and an emission of $509 \mathrm{~nm}$ ), due to the incorporation of the fluorescent indicator calcein (Dissard et al. 2009). For the subsequent chemical analysis, we selected individual foraminifers $(>150 \mu \mathrm{m})$, where chamber formation or chamber wall thickening of the whole shell was clearly identified. Smaller specimens $(<150 \mu \mathrm{m})$ were too fragile for further analyses and chamber wall thickness was below the detection limit $(<1 \mu \mathrm{m})$ of the electron microprobe. 


\section{Scanning electron microscopy}

A Scanning Electron Microscope (SEM) was used to study morphological features of the foraminifera shells to visualize differences in the microstructural surface quality between new and pre-existing chambers and to exclude dissolution of the shells. To obtain high-resolution images of foraminiferal shells by SEM, whole individuals were fixed on adhesive carbon platelets and coated with $20 \mathrm{~nm}$ of carbon to reduce electric charge. The instrument JEOL JSM-6610LV SEM (Institut für Planetologie, Universität Münster) was used with an acceleration voltage of $20 \mathrm{kV}$, a working distance of 13-15 $\mathrm{mm}$, a spot size of $58 \mu \mathrm{m}$, a beam current of $10^{-6} \mathrm{~A}$ under a vacuum of $3 \times 10^{-6} \mathrm{mbar}$. The images were generated by secondary electrons.

\section{Electron microprobe}

Individual foraminifers were embedded in epoxy resin under vacuum and polished to get a single chamber cross section with a planar surface. Samples were coated with $20 \mathrm{~nm}$ of carbon. The measurements were conducted using the Electron Microprobe JEOL JXA 8900 Superprobe (Institut für Mineralogie, Universität Münster). The elemental analysis was performed by using an acceleration voltage of $15 \mathrm{kV}$ and a beam current of $12 \mathrm{nA}$. Element concentrations of $\mathrm{Mg}, \mathrm{Ca}$, $\mathrm{Na}$, and $\mathrm{Sr}$ were identified by quantitative wavelength dispersive X-ray analysis. Element concentrations were determined by 2 to 9 single point measurements along with the inner layer of chamber wall cross sections. The probe diameter varied between 1 and $5 \mu \mathrm{m}$, because the thickness of chamber wall cross sections differed between newly formed and preexisting chambers. To obtain element distribution maps of chambers the acceleration voltage was set to $15 \mathrm{kV}$, the beam current to $15 \mathrm{nA}$ with $150 \mathrm{~ms}$ on peak position, and a probe diameter of $1 \mu \mathrm{m}$. The following reference materials were used for $\mathrm{Ca}, \mathrm{Mg}, \mathrm{Sr}$, and $\mathrm{Na}$ : USNM 136321 Calcite, Astimex Mineral Standard (Calcite), USNM 10057 Dolomite, NMNH R 10065 Strontianite, and 1913/451 Jadeite ST6. The precision between single measurements (given as the relative standard deviation $=($ standard deviation $1 \sigma /$ mean value) $\times 100$ ) and accuracy (given as the relative error in $\%$; deviation between actual measured and reference values) is equal or $\leq 1 \%$ for all measured reference materials. Calcium intensities (wt $\%$ ) deviating more than $10 \%(2 \sigma)$ from the maximum $\mathrm{Ca}$ intensity are defined as outliers and excluded for further analysis. All $\mathrm{Mg} / \mathrm{Ca}, \mathrm{Sr} / \mathrm{Ca}$ and $\mathrm{Na} / \mathrm{Ca}$ results were tested for normal distribution applying the Shapiro-Wilk test. Corresponding $p$ values smaller than $<0.05$ (95\% confidence interval) indicate that samples are not normally distributed. If measurements are normally distributed, Pearson's correlation coefficient $R$ and its respective $p$ values describe the significance between trace element values and experimental settings (here salinity). Values are considered significant if $p$ is $<0.05$ and according to that $R$ differs ( $>95 \%$ confidence interval) from 0 in the range of 1 to -1 , describing a positive or negative linear relationship. To additionally prove the reproducibility and reliability of single-chamber analysis, we used the time-of-flight secondary ion mass spectrometry (ToF-SIMS). Trace element ratios resulting from ToF-SIMS analysis are presented as non-calibrated ratios in counts per second (cps) because no appropriate calibration standard existed at the time of measurements. The method and respective settings are explained in detail in Appendix 2.

\section{Results}

\section{Chamber formation during culture experiments}

Culture experiments were conducted at salinities varying between 30 and 83 (Table 1). At salinities of 30, 31, and 69, newly grown chambers of $N$. pachyderma were identified, characterized by its calcein-labeling. For the remaining experiments, calcein-labeling was only prominent along with the whole shell of $N$. pachyderma individuals (Table 1, Fig. 2). The release or presence of gametes was not observed during all experiments.

In detail, $30 \%$ of foraminifers $(\leq 150 \mu \mathrm{m})$ calcified one to two new chambers (F, F-1) in the culture at a salinity of 69 (experiment 506g-10) (Fig. 2). Foraminifers being at a later life-stage $(\leq 250 \mu \mathrm{m})$, representing $1.6 \%$ of all cultured foraminifers at S 69 , are calcein-labeled throughout the whole shell. The remaining individuals of this experiment did not show any calcein-labeling or indication for growths.

Half of the foraminifers $(\leq 100 \mu \mathrm{m})$, which have been grown in the culture at a salinity of 31 (experiment 506g-7), added new calcein-labeled chambers (F, F-1). Two larger specimens $(\leq 250 \mu \mathrm{m})$ revealed chamber wall thickening at S 31, indicated by its fluorescence of the whole shell (Table 1). At a salinity of 30 , only one individual added a new chamber. Cultured foraminifers of the remaining experiments (S 46 to S 83) revealed chamber wall thickening only, indicated by the fluorescence of the whole shell, or showed in a few cases a reddish fluorescence (Table 1, Fig. 2).

With respect to the foraminiferal surface structure, secondary electron images revealed differences between newly added chambers in culture and those calcified prior to the experiments (Fig. 3). Newly calcified chambers are characterized by a smooth surface with rarely scattered crystals in contrast to previously formed chambers grown in the natural environment (Fig. 3f, g). Older chambers are more heavily encrusted and covered by dense and coarser calcite crystals $\leq 1-2 \mu \mathrm{m}$. Crystals vary in size and are not homogenously distributed at the chambers. Further observations show that some newly grown chambers are irregular or oversized (Fig. 

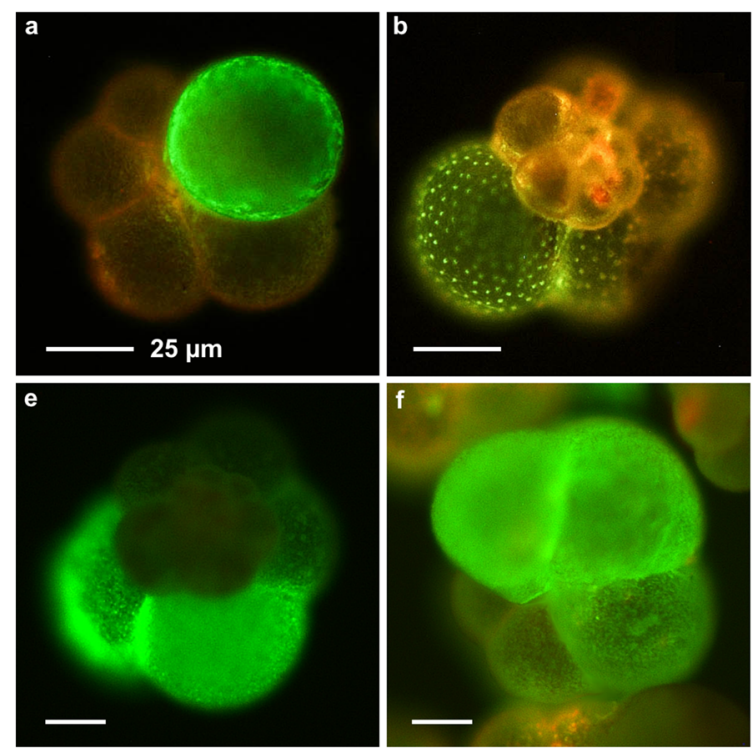

Fig. 2 Examples of cultured $N$. pachyderma (s) specimens, showing new calcified chambers in culture, indicated by the greenish fluorescence of the calcein dye under UV-light in the final chamber F (a, b, d, h) and its penultimate F-1 (e, g, h), F-2 (f). The white scale bar indicates $25 \mu \mathrm{m}$ for

3c, d). Cultured foraminifers marked by a calcein-labeling of the whole shell did not reveal any differences of the outer surface structure between chambers, whereas chamber wall cross sections exposed clear differences in the calcite structure of the inner and outer calcite layer (Fig. 3a, b, e).

\section{Trace element incorporation into N. pachyderma shells}

\section{$\mathrm{Mg} / \mathrm{Ca}$}

For $N$. pachyderma specimens that were cultured at a salinity of 69 , average $\mathrm{Mg} / \mathrm{Ca}$ values vary from 1.14 to $2.10 \mathrm{mmol} /$ mol between newly calcified chambers, presenting a standard deviation of $30.3 \%$ (Table 2, Fig. 5). Electron microprobe single spot measurements for single chambers are shown in the Appendix 1 (Table 3, Fig. 8). Average $\mathrm{Mg} / \mathrm{Ca}$ values of calcified chambers before the experiments vary from 0.27 to $1.86 \mathrm{mmol} / \mathrm{mol}$ (SD: $39.3 \%$ ) between specimens (Table 2). Single spot $\mathrm{Mg} / \mathrm{Ca}$ values show a higher variability within newly grown chambers in the culture at $\mathrm{S} 69$, varying between 0.16 and $6.43 \mathrm{mmol} / \mathrm{mol}$, compared with prior chambers (F-1, F-2: 0.24 and $3.76 \mathrm{mmol} / \mathrm{mol}$; Appendix 1, Table 3).

Nevertheless, $\mathrm{Mg} / \mathrm{Ca}$ values are not normal-distributed for the culture experiments at S 69 (Shapiro-Wilk test: $p=0.002$, $W=0.63$ ). Accordingly, no significant $\mathrm{Mg} / \mathrm{Ca}$ trend $(p=0.65$, $R=0.12$ after Pearson's linear correlation) with increasing salinities is observed between chambers grown in the culture at $S 31$ and S 69, including values of naturally grown ones before culture at surface waters of $\sim \mathrm{S} 34$ (or at the sea ice interface: S $34-48$ ). However, the data tentatively suggest a

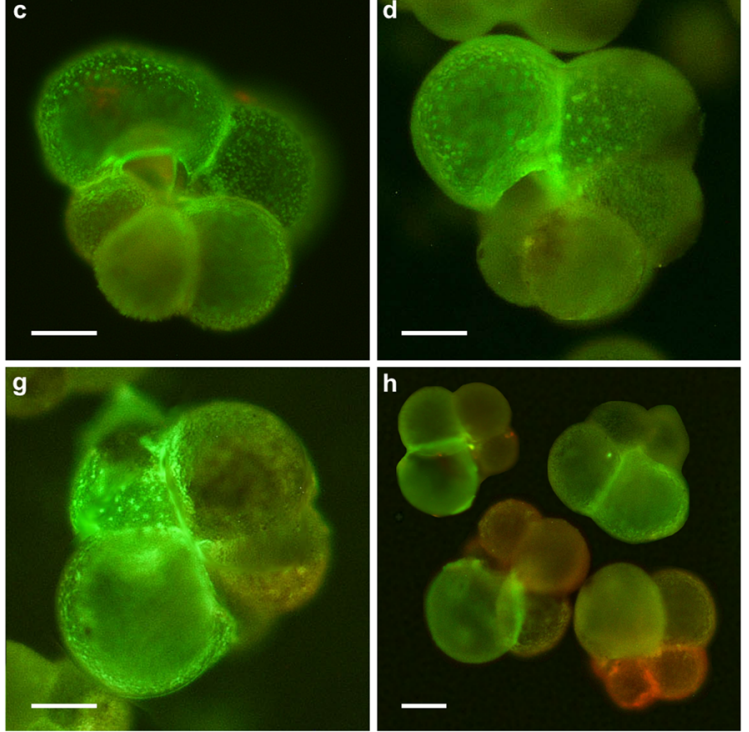

all images. Images (a-d) and (f-h) show foraminifers from culture experiments at a salinity of 69 , and image (e) gives an example of chamber formation at a salinity of 31 . Image (c) presents one foraminifer, showing a greenish fluorescence throughout the whole shell

certain tendency, which should not be disregarded, as $\mathrm{Mg} / \mathrm{Ca}$ values are high at S 69 and clearly exceed the variability of chambers grown before to the start of the experiment (cf. Figs. 5 and 6). Shell $\mathrm{Mg} / \mathrm{Ca}$ results are qualitatively supported by additional measurements applying the ToF-SIMS. Similar trends between single chambers related to a salinity increase are apparent from the ToF-SIMS (Fig. 9) and the electron microprobe analysis (Fig. 6). Considering the element distribution within new calcified chambers in culture, prominent $\mathrm{Mg} / \mathrm{Ca}$ banding is obvious, whereas $\mathrm{Na} / \mathrm{Ca}$ and $\mathrm{Sr} / \mathrm{Ca}$ ratios are less pronounced, showing no banding throughout chamber wall cross sections (Fig. 4).

\section{$\mathrm{Sr} / \mathrm{Ca}$}

Average $\mathrm{Sr} / \mathrm{Ca}$ ratios vary between 1.38 and $1.89 \mathrm{mmol} / \mathrm{mol}$ (SD: $12.5 \%$ ) for newly grown chambers (F) at S 69. For preculture grown chambers, ratios vary between 1.15 and 1.86 mmol/mol (SD: $14.5 \%$ ) (Table 2, Fig. 5). The intra-shell variability of $\mathrm{Sr} / \mathrm{Ca}$ values within newly formed chambers is in agreement with pre-existing chambers. These single spot measurements are listed in the Appendix 1 (Table 3). Further, $\mathrm{Sr} / \mathrm{Ca}$ ratios are rather homogenously distributed throughout new calcified chambers (Fig. 4) and are normally distributed for all experiments (Shapiro-Wilk test: $p=0.89, W=0.97$ ). A slight, but not statistically significant positive correlation is obvious for $\mathrm{Sr} / \mathrm{Ca}$ ratios with increasing salinities $(p=0.12$, $R=0.42$ ) from $\sim \mathrm{S} 34$ at surface waters (or S $34-48$ at the sea ice interface) in the natural environment to $\mathrm{S} 69$ in culture, shown in Fig. 5. Results of cultured foraminifers at S 31 exhibit higher $\mathrm{Sr} / \mathrm{Ca}$ values $(1.87 \pm 0.15 \mathrm{mmol} / \mathrm{mol}$ in chamber 

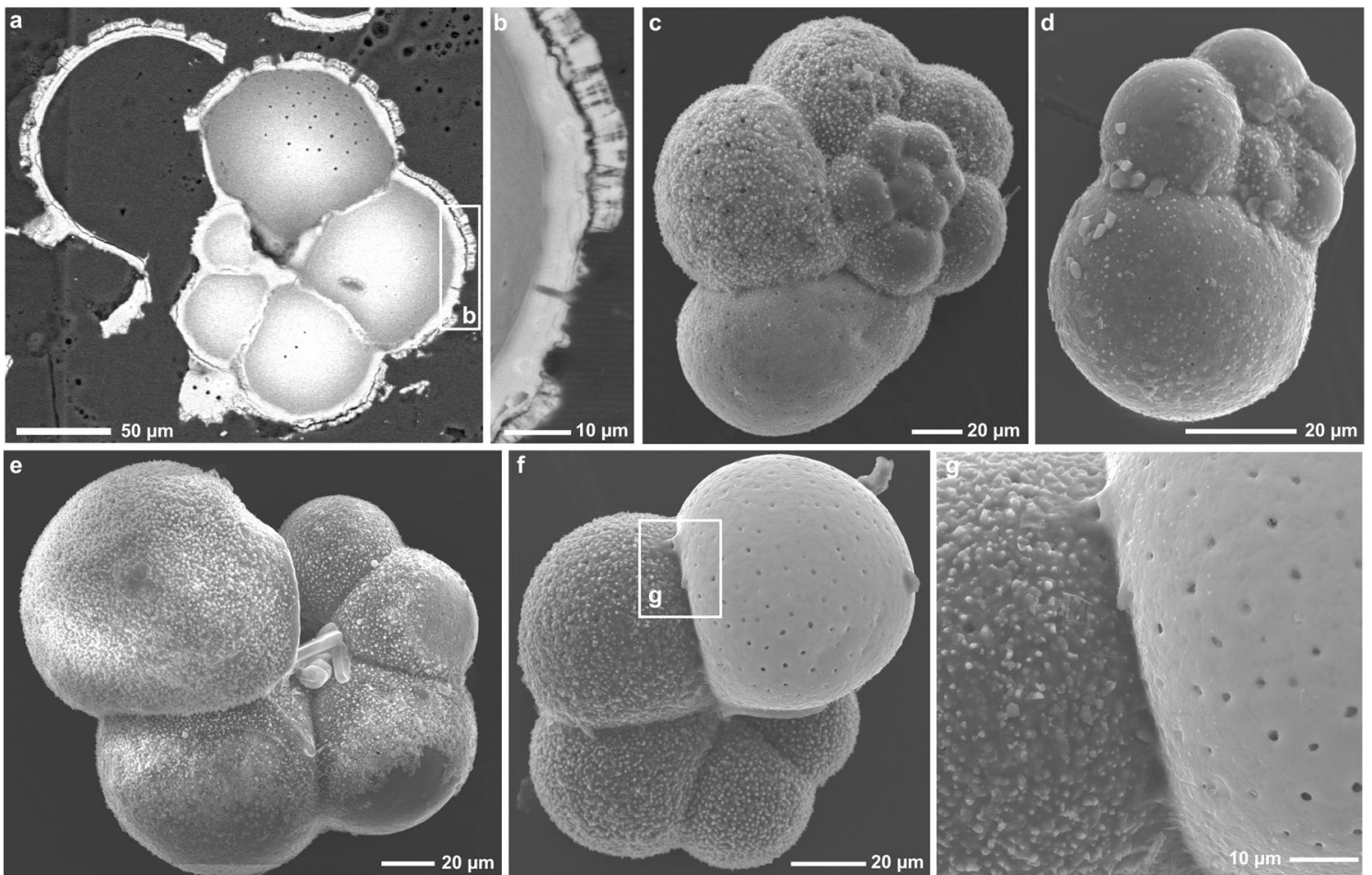

Fig. 3 Examples of cultured $N$. pachyderma (s) secondary electron images applying the scanning electron microscopy. a Chamber wall cross section of a cultured individual, showing chamber wall thickening over pre-grown chambers in the culture at a salinity of 31 , indicated by its greenish fluorescence (Fig. 2). Differences between the inner and outer calcite layer are clearly visible by zooming in (b), whereas the surface structure between chambers does not differ (e). c, f Both foraminifers calcified a new chamber $\mathrm{F}$ in culture (calcein-labeled) at a salinity of 69, revealing a planar surface without crystals (g). d Smaller, juvenile individuals $>40 \mu \mathrm{m}$ mostly formed an irregular, oversized chamber $\mathrm{F}$ in culture. Compared with larger sub-adult specimens (e), the surface of the whole shell is not yet stabilized by coarser crystals
Table 2 Average element values for cultured N. pachyderma (s) are shown for each chamber $(\mathrm{F})$ newly grown in the culture at different salinities and a constant temperature $\left(-1\right.$ to $\left.+2{ }^{\circ} \mathrm{C}\right)$. Chambers F-1 and $\mathrm{F}-2$ have been grown prior to the culture experiments most likely at the sea surface (S 34) or at the sea ice interface (S 34-48) (WOA2013; Lemke 2014b; Tison et al. 2008). Average element/Ca uncertainties are based on the standard error of the mean $\pm \mathrm{SE}(\sigma / \sqrt{ } n)$. Measurements were conducted by the electron microprobe analyses. The number of single measurements is given as nm and corresponding single values are presented in the Appendix 1 (Table 3)

\begin{tabular}{|c|c|c|c|c|c|c|c|c|c|}
\hline Specimen no. & Chamber & $\mathrm{nm}$ & Salinity & $\mathrm{Na} / \mathrm{Ca}(\mathrm{mmol} / \mathrm{mol})$ & SE & $\mathrm{Mg} / \mathrm{Ca}(\mathrm{mmol} / \mathrm{mol})$ & SE & $\mathrm{Sr} / \mathrm{Ca}(\mathrm{mmol} / \mathrm{mol})$ & SE \\
\hline 1 & $\mathrm{~F}$ & 7 & 69 & 8.08 & 0.63 & 2.10 & 0.54 & 1.61 & 0.16 \\
\hline 1 & F-1 & 8 & 34 & 5.65 & 0.56 & 1.09 & 0.20 & 1.45 & 0.12 \\
\hline 1 & F-2 & 4 & 34 & 5.91 & 0.52 & 1.09 & 0.19 & 1.41 & 0.25 \\
\hline 2 & $\mathrm{~F}$ & 3 & 69 & 9.26 & 1.49 & 1.14 & 0.10 & 1.89 & 0.18 \\
\hline 2 & F-1 & 4 & 34 & 8.18 & 1.18 & 1.10 & 0.46 & 1.26 & 0.20 \\
\hline 2 & F-2 & 5 & 34 & 8.13 & 0.80 & 1.27 & 0.30 & 1.49 & 0.28 \\
\hline 3 & $\mathrm{~F}$ & 8 & 69 & 9.17 & 0.57 & 1.15 & 0.32 & 1.79 & 0.15 \\
\hline 3 & $\mathrm{~F}-1$ & 3 & 34 & 7.16 & 0.76 & 0.27 & 0.10 & 1.22 & 0.09 \\
\hline 3 & $\mathrm{~F}-2$ & 6 & 34 & 6.33 & 0.84 & 0.81 & 0.19 & 1.15 & 0.12 \\
\hline 4 & $\mathrm{~F}$ & 26 & 69 & 8.23 & 0.43 & 1.20 & 0.12 & 1.38 & 0.10 \\
\hline 4 & F-1 & 23 & 34 & 6.83 & 0.31 & 1.70 & 0.14 & 1.44 & 0.09 \\
\hline 5 & $\mathrm{~F}$ & 5 & 69 & 6.61 & 1.18 & 1.23 & 0.29 & 1.52 & 0.44 \\
\hline 5 & F-1 & 5 & 34 & 6.34 & 0.78 & 1.86 & 1.15 & 1.65 & 0.18 \\
\hline 6 & $\mathrm{~F}$ & 9 & 31 & 5.88 & 0.30 & 1.24 & 0.14 & 1.87 & 0.18 \\
\hline 6 & F-1 & 10 & 34 & 8.46 & 0.75 & 1.77 & 0.20 & 1.86 & 0.10 \\
\hline 6 & F-2 & 11 & 34 & 7.34 & 0.51 & 1.59 & 0.13 & 1.54 & 0.09 \\
\hline
\end{tabular}




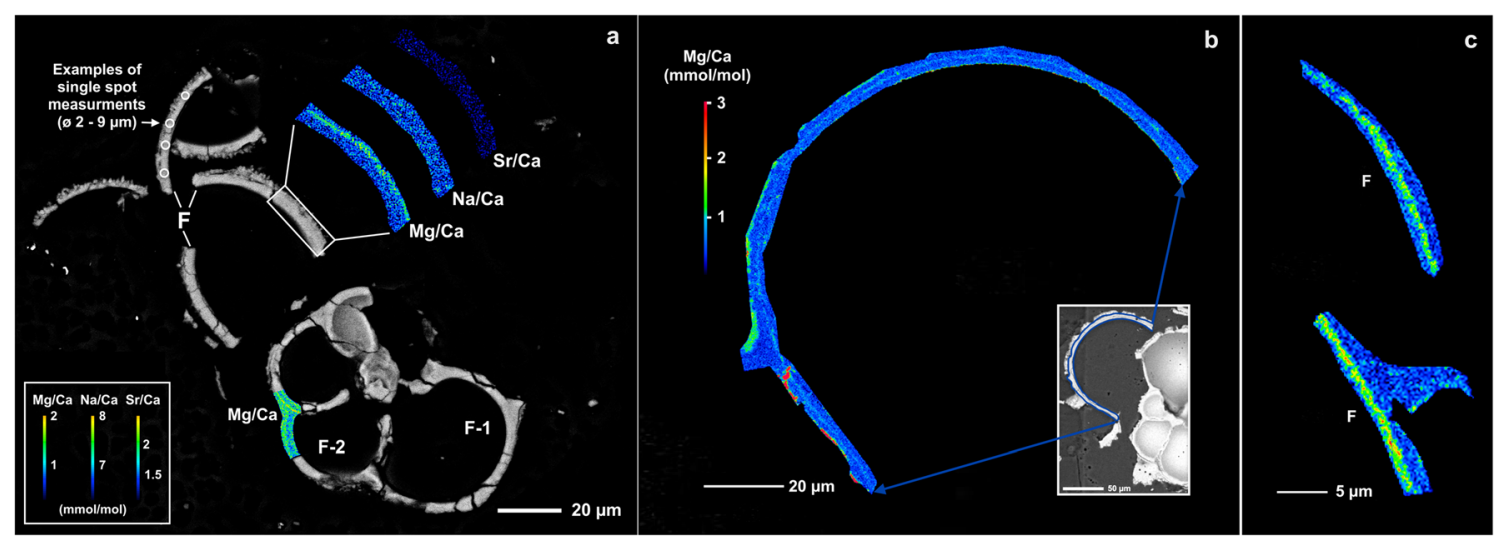

Fig. 4 a Example of a secondary electron image showing the chamber wall cross section from one cultured $N$. pachyderma (s) specimen at a salinity of 69 and its respective element distribution maps generated with the electron microprobe. Single spot measurements (white circles) were used for elemental analysis, whereas the spot size varied from 1 to $5 \mu \mathrm{m}$ in size, dependent on the chamber thickness of newly grown chambers (F) in culture. Chambers F-1 and F-2 have been grown presumably in the natural environment before the onset of experiments. For the element analysis, two to six single spots were set at each chamber, presented in

F) than pre-existing chambers of the same individual ( $\sim$ S 34, $1.54-1.86 \mathrm{mmol} / \mathrm{mol})$, but do not differ from results of experiments at S 69 (Table 2). Results of ToF-SIMS analysis confirm the higher $\mathrm{Sr} / \mathrm{Ca}$ values at apparently lower salinity of 31 (Appendix 2).

\section{$\mathrm{Na} / \mathrm{Ca}$}

Average $\mathrm{Na} / \mathrm{Ca}$ ratios for each newly grown chamber in culture (S 69) are within the range of 6.61-9.26 $\mathrm{mmol} / \mathrm{mol}$ (SD: $12.9 \%$ ), while $\mathrm{Na} / \mathrm{Ca}$ ratios are lower $(5.65-8.18 \mathrm{mmol} / \mathrm{mol}$, SD: $14.1 \%$ ) in pre-existing chambers (F-1, F-2) (Table 2, Fig. 5). All $\mathrm{Na} / \mathrm{Ca}$ values of single spot measurements are shown in the Appendix (Table 3). In all analyzed specimens, average $\mathrm{Na} / \mathrm{Ca}$ values were higher in the final chambers than in the pre-experimentally calcified ones. Also, $\mathrm{Na} / \mathrm{Ca}$ values are normally distributed for all experiments (Shapiro-Wilk test: $p=$ $0.38, W=0.89$ ) and show a slight, but statistically significant positive correlation ( $p=0.02, R=0.55$ ) between chambers grown in the culture at S 31 and S 69, including naturally grown chambers in the pelagic ocean at the sea surface $(\sim \mathrm{S}$ 34 ) or the sea ice interface (S 34-48). This trend also holds for additional ToF-SIMS measurements (Appendix 2). Compared with the intra-shell variability of $\mathrm{Mg} / \mathrm{Ca}$ and $\mathrm{Sr} / \mathrm{Ca}, \mathrm{Na} / \mathrm{Ca}$ ratios exhibit high variations between 3.30 and $11.49 \mathrm{mmol} /$ mol within single chambers for S 69, which is in agreement to preceding chambers: 3.47-10.96 $\mathrm{mmol} / \mathrm{mol}$ (Fig. 5). Nevertheless, such high $\mathrm{Na} / \mathrm{Ca}$ values are rare and isolated. Considering $\mathrm{Na} / \mathrm{Ca}$ distribution maps, no banding occurs within chamber wall cross sections and ratios are homogeneously distributed similarly to $\mathrm{Sr} / \mathrm{Ca}$ (Fig. 4). Results for
Fig. 5 as light gray dots. No distribution patterns are obvious for $\mathrm{Na} / \mathrm{Ca}$ and $\mathrm{Sr} / \mathrm{Ca}$ values throughout chamber wall cross sections, whereas $\mathrm{Mg}$ / $\mathrm{Ca}$ banding is clearly noticeable. $\mathbf{b} \mathrm{Mg} / \mathrm{Ca}$ distribution map of one foraminifer that showed chamber wall thickening during the experiments at a salinity of 31. Chamber F shows one distinct band, enriched in $\mathrm{Mg} / \mathrm{Ca}$, in the vicinity to a primary organic sheet, visible by cracks at secondary electron images (Fig. 3a, b). c Example of $\mathrm{Mg} / \mathrm{Ca}$ distribution maps from chambers grown in culture at a salinity of 69 , showing clear differences in $\mathrm{Mg} / \mathrm{Ca}$ values between the inner and outer calcite layer

cultured foraminifers at a salinity of 31 exhibits the lowest average $\mathrm{Na} / \mathrm{Ca}$ values of $5.88 \pm 0.30 \mathrm{mmol} / \mathrm{mol}$ in chamber F (Fig. 5).

\section{Discussion}

\section{Chamber calcification of $N$. pachyderma in a sea ice environment}

This study clearly shows the ability of juvenile to pre-adult $N$. pachyderma specimens to add new chambers under extreme culture conditions (S 30-69), related to the chemical composition of natural sea ice brines. Chamber wall thickening was even observed up to salinities of S 83 in culture. With regard to paleoenvironmental reconstructions, foraminiferal calcification within sea ice brines has the potential to change the geochemical shell signature (cf. sec. 4.3).

Salinity tolerance limits of planktonic foraminifers have rarely been recorded so far. The study of Bijma et al. (1990) described the response of cultured spinose planktonic foraminifera from mid-latitudes to extreme salinity changes, at which Trilobatus sacculifer and Globigerinoides ruber show the ability to calcify and reproduce until salinities of 47 to 49 , respectively. Such high salinities would not be expected in the paleo-record at the latitudes where these species are found. However, N. pachyderma is an exception due to its occurrence at high latitudes where sea ice can be found. Reproduction of $N$. pachyderma mainly occurs in autumn, which affects juvenile to sub-adult $(<200 \mu \mathrm{m})$ foraminifers in the way that these are most abundant in surface waters $(0-200 \mathrm{~m})$ at the onset of 

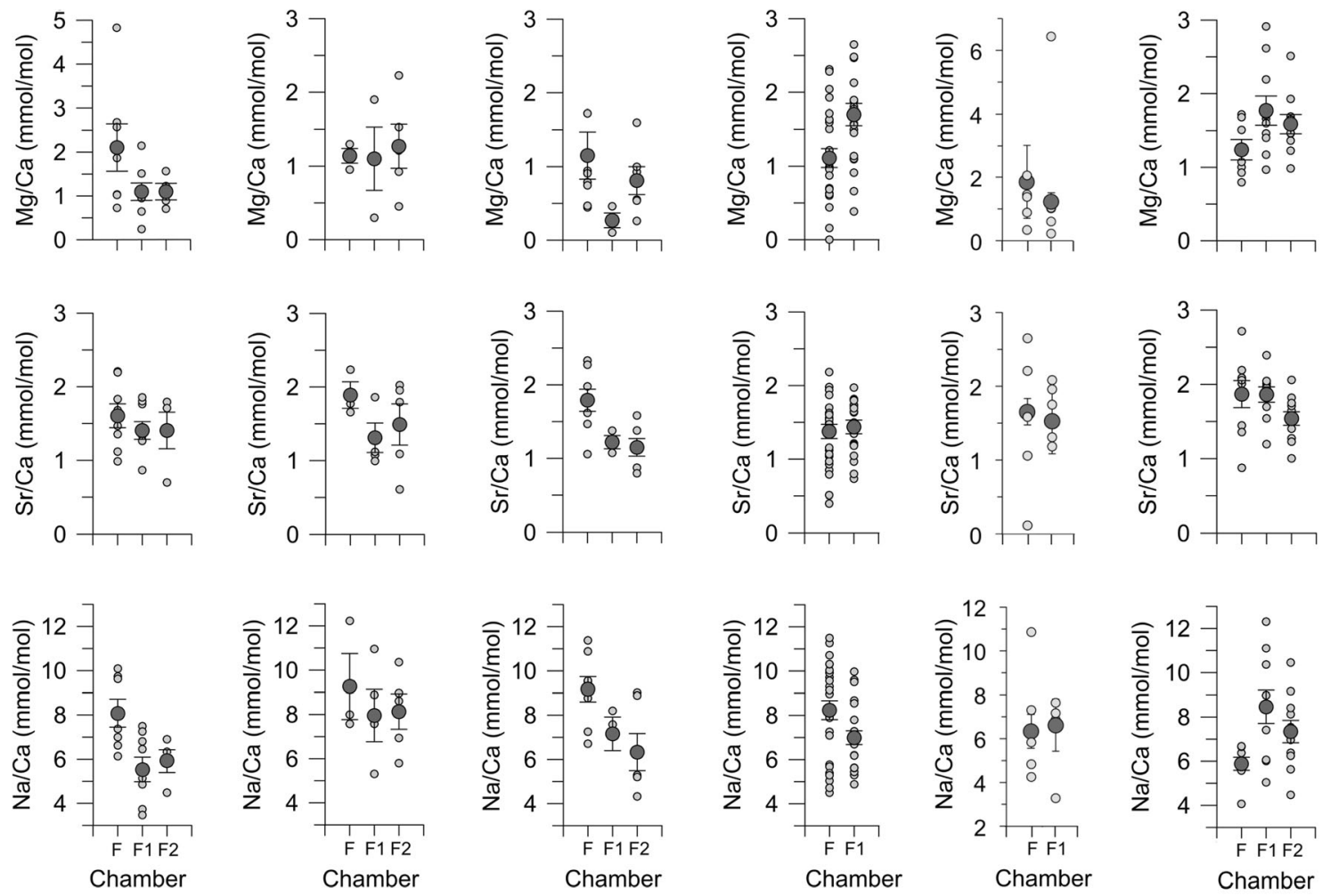

\section{F: calcified at S 69}

F: S 31

Fig. 5 Average $\mathrm{Mg} / \mathrm{Ca}, \mathrm{Sr} / \mathrm{Ca}$, and $\mathrm{Na} / \mathrm{Ca}$ results of cultured $N$. pachyderma (s) measured by single spot analysis applying the electron microprobe technique (cf. Table 2, Appendix-Table 3). Each plot represents one foraminifer specimen. Small light gray dots show one single spot measurement on chamber wall cross sections for one foraminifer. Dark gray dots show the average value for one chamber (F, F-1, F-2) and vertical error bars mark the standard error of the mean $(\sigma / \sqrt{ } n)$. Chosen foraminifers have shown a greenish fluorescence under UV-light and thus, incorporated the fluorescent dye calcein during culture experiments while forming a new chamber (F) under controlled conditions. Penultimate chambers (F-1, F-2) are expected to be formed in the natural habitat, either at the sea surface (S 34) or at the sea ice interface (S 34-48) (WOA2013; Lemke 2014b; Tison et al. 2008)
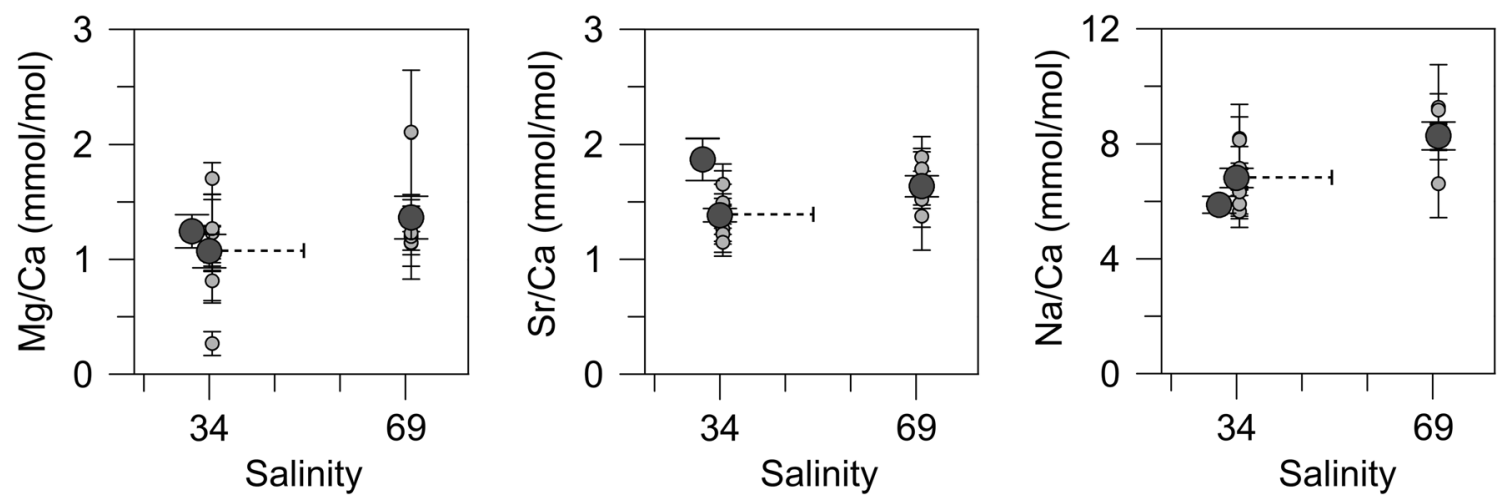

Fig. 6 Average trace element values of cultured N. pachyderma (s) specimens that have formed new chambers in the culture at salinities of 31 and 69. Each small light gray dot shows average $\mathrm{Mg} / \mathrm{Ca}, \mathrm{Sr} / \mathrm{Ca}$, and $\mathrm{Na} / \mathrm{Ca}$ ratios for one foraminifer out of single spot measurements applying the electron microprobe technique. Large dark gray dots show the average of all analyzed foraminifers at certain salinities. Vertical error bars are given as the standard error of the mean $(\sigma / \sqrt{ } n)$. Element ratios presented for a salinity of S 34 result from naturally grown chambers (F-1, F-2) prior to culture experiments. Chambers were potentially calcified at sea surface waters at S 34 or at the sea ice interface (S 34-48) (WOA2013; Lemke 2014b; Tison et al. 2008). The dashed horizontal error bar marks the potential salinity range of pre-grown chambers. Single values are shown in Table 2 
yearly sea ice formation in the Weddell Sea (Spindler and Dieckmann 1986). Individuals are easily incorporated into the new freezing ice and continue living in highly saline brine channels. Foraminiferal abundances in the ice are around two orders of magnitude higher per liter than in the underlying water column (Dieckmann et al. 1991). Although the study of Spindler and Dieckmann (1986) could show that $N$. pachyderma is alive and actively feeding within the sea ice, also during winter months (Spindler 1996), there is not yet evidence that $N$. pachyderma can undergo gametogenesis and can reproduce within the ice. Culture experiments by Spindler (1996) showed that $N$. pachyderma specimens were able to add chambers until a salinity of 58 and survived for a few days at a salinity of 82 at $-1{ }^{\circ} \mathrm{C}$. These observations are confirmed by our culture experiments, even extending chamber wall thickening at higher salinities up to 83 . Chamber thickening is probably related to the ontogenetic development as no gametes or reproduction signs were visible throughout the experiments. Chamber formation within our culture experiments is also in agreement with earlier observations by Berberich (1996), indicating that the shell size of foraminifers probably increases with increasing sea ice age (inferred from its diameter). Berberich (1996) hypothesized that foraminifers can migrate through brine channels back to the free water column if they reach their respective shell size for reproduction $(>\sim 200 \mu \mathrm{m})$. Foraminifera, however, only showed prereproduction signs in the sea ice (Berberich 1996). On this basis, our results were able to show that foraminifera could still calcify after abrupt salinity changes within a short period of time, when specimens were placed from the natural habitat $(\sim S 34)$ into a culture medium with a salinity up to 83 . However, chamber formation could be inhibited as we observed numerous individuals with unshaped and extremely large, elongated final chambers that exceeded the previously precipitated chambers by 2 to 3 times. This observation is contrary to that of Spindler (1996), reporting enhanced occurrences of smaller chambers (kummerforms) at higher salinities. Unshaped chambers might be an indicator of ecological stress in the culture. Nevertheless, indications of irregular chamber growth or the consideration of structural differences between the final calcified chamber at high salinities to preceding chambers, calcified in the pelagic ocean, can be used to identify possibly individual foraminifera from a sea ice environment. This suggestion needs further elaboration in future studies and would require the comparison of living foraminifers collected from sea ice to foraminifera from sediment traps or core-tops.

Besides the ability for calcification in an extreme environment, the survival of foraminifera in sea ice is further limited and strongly dependent on its ice structure, temperature, sea ice freezing or melting, food availability, and food acceptance (Spindler and Dieckmann 1986; Tison et al. 2002, 2008; Papadimitriou et al. 2007). Foraminifers mainly feed on diatoms, which are most abundant and able to reproduce within the ice at salinities between 34 to 150 , and temperatures below $-1^{\circ} \mathrm{C}$, whereby the temperature is not the critical factor (Buinitsky 1977; Spindler and Dieckmann 1986; Bartsch 1989). Although sufficient food sources would be available, culture experiments of Spindler (1996) showed that $N$. pachyderma is not able to feed anymore above salinities of 73 due to the limitation of their pseudopodia activity. These observations would imply that foraminifers are possibly not able to move or feed again and would starve after a certain period of time in the ice (Spindler 1996). Pseudopodia networks are also known to actively support calcification processes (Erez 2003; Bentov and Erez 2005). Nevertheless, our experiments could even prove chamber wall thickening at salinities of 83. We would hypothesize that other external or internal factors rather than the limitation of pseudopodia activity alone are responsible for ongoing foraminifer calcification processes within conditions expected in sea ice brines. The study by Papadimitriou et al. (2007) indicated that the chemical composition of sea ice brines is exposed to elevated $\mathrm{pH}$ values (8.4-8.8), dissolved oxygen, and concentrations of $\delta^{13} \mathrm{C}$ compared with the underlying seawater in the austral summer/autumn, but depleted in dissolved carbon dioxide and total dissolved inorganic carbon. Taking this into account, earlier studies suggested that foraminifers can transform $\mathrm{CO}_{2}$ or $\mathrm{HCO}_{3}{ }^{2-}$ to $\mathrm{CO}_{3}{ }^{2-}$ at higher $\mathrm{pH}$ values at the site of calcification, which further promotes calcite precipitation (Erez 2003; Bentov et al. 2009; De Nooijer et al. 2009, 2014; Toyofuku et al. 2017). Hence, different chemical brine compositions compared with those of seawater could change calcification processes.

\section{Estimating the effect of salinity on element incorporation into foraminiferal calcite}

\section{$\mathrm{Mg} / \mathrm{Ca}$}

Our $\mathrm{Mg} / \mathrm{Ca}$ results $(1.07 \mathrm{mmol} / \mathrm{mol} \pm 0.15 \mathrm{SE})$ of $N$. pachyderma (s) chambers that have been grown in the natural environment before the onset of culture experiments are broadly consistent with $\mathrm{Mg} / \mathrm{Ca}$ results of previous studies (e.g., Hendry et al. 2009; Jonkers et al. 2013; Meland et al. 2006). The consistency of $\mathrm{Mg} / \mathrm{Ca}$ values between living foraminifers (collected for our culture experiments) and specimens from sediment traps strengthens the reliability of our electron microprobe based single foraminifer analysis. However, $\mathrm{Mg} / \mathrm{Ca}$ values of newly calcified chambers in the culture at salinities of 69 reveal on average higher $\mathrm{Mg} / \mathrm{Ca}$ values $(1.36 \mathrm{mmol} / \mathrm{mol} \pm 0.27 \mathrm{SE})$ compared with values from pre-culture grown chambers and the fossil record. Illustrated by one example, specimens of $N$. pachyderma collected from sediment traps in the West Antarctic Peninsula in the vicinity to our study area exhibit $\mathrm{Mg} / \mathrm{Ca}$ values of $0.77-1.06 \mathrm{mmol} /$ 
mol throughout the year with a seasonal peak and highest $\mathrm{Mg}$ / Ca values during the austral winter (Hendry et al. 2009). The observed differences between $\mathrm{Mg} / \mathrm{Ca}$ results from cultured foraminifers at high salinities and specimens from sediment traps would imply that the chemical composition of the culture medium, similar to that of sea ice brines, significantly affects the geochemical signature of foraminifera (Figs. 4c and 6). Therefore, we discuss in the following potential external and internal controls on $\mathrm{Mg} / \mathrm{Ca}$ incorporation into foraminiferal calcite.

It has been previously shown that foraminiferal $\mathrm{Mg} / \mathrm{Ca}$ is primarily controlled by ocean temperature, resulting in an exponential increase by $\sim 8$ to $10 \%$ per degree Celcius for Trilobatus sacculifer, Globigerina bulloides, Orbulina universa, and Neogloboquadrina dutertrei and $6.0-6.7 \% /{ }^{\circ} \mathrm{C}$ for G. ruber (w) (Anand et al. 2003; Dueñas-Bohórquez et al. 2009; Elderfield and Ganssen 2000; Gray et al. 2018; Gray and Evans 2019; Hönisch et al. 2013; Kisakürek et al. 2008; Lea et al. 1999; Nürnberg et al. 1996; Regenberg et al. 2009; Russell et al. 2004). Due to the exponential nature of the temperature dependence, the foraminiferal $\mathrm{Mg} / \mathrm{Ca}$ variability at high latitudes is relatively small. Assuming that $N$. pachyderma (s) is calcifying within the sea ice brine, chemical parameters other than temperature are changing in the brine compared with the seawater and, hence, could additionally influence the trace element uptake into calcite shells. Increasing seawater salinity enhances $\mathrm{Mg} / \mathrm{Ca}$ incorporation by $2-5 \%$ per $\mathrm{S}$ unit, known from culture experiments (Arbuszewski et al. 2010; Dueñas-Bohórquez et al. 2009; Gray et al. 2018; Hönisch et al. 2013; Kisakürek et al. 2008; Lea et al. 1999; Nürnberg et al. 1996). A salinity change of 4 units would introduce a temperature change of $\pm 1{ }^{\circ} \mathrm{C}$ for $\mathrm{Mg}$ / $\mathrm{Ca}$ paleotemperature reconstructions (Dueñas-Bohórquez et al. 2009). Increasing seawater $\mathrm{pH}$ and related $\left[\mathrm{CO}_{3}{ }^{2-}\right]$ would affect shell $\mathrm{Mg} / \mathrm{Ca}$ towards decreasing ratios by -5 to $-9 \%$ per $0.1 \mathrm{pH}$ unit increase below a $\mathrm{pH}<8.2-8.7$ (Allen et al. 2016; Evans et al. 2016; Gray et al. 2018; Kisakürek et al. 2008; Lea et al. 1999; Regenberg et al. 2006; Russell et al. 2004; Spero et al. 2015). It was hypothesized for a glacial scenario with a postulated increase in salinity by 1 unit and in $\mathrm{pH}$ by 0.2 (Sanyal et al. 1996) that the opposite effect of both parameters on shell $\mathrm{Mg} / \mathrm{Ca}$ partially cancel each other (Lea et al. 1999; Nürnberg 2000). However, brine salinities could exceed values above S 150 (Berberich 1996), whereas maximum $\mathrm{pH}$ values of $\sim 8.4-8.8$ are reported for first-year sea ice brines (Papadimitriou et al. 2007). Therefore, we assume that salinity is one of the driving parameters over $\mathrm{pH}$ and temperature, controlling $\mathrm{Mg}$ incorporation into foraminiferal calcite within brine channels of sea ice. To underline this assumption, average $\mathrm{Mg} / \mathrm{Ca}$ values ( $\mathrm{S}$ 69) of our study are higher than those reported by Elderfield and Ganssen (2000) and do not fit on the exponential line, which is based on the $\mathrm{Mg} / \mathrm{Ca}$ to calcification temperature relationship. As the temperature was held constant throughout our experiments, $\mathrm{Mg} / \mathrm{Ca}$ variations cannot solely be explained by seasonal temperature variations (Eggins et al. 2003, 2004; Sadekov et al. 2005).

Considering the $\mathrm{Mg} / \mathrm{Ca}$ variability within $N$. pachyderma shells, inter-shell $\mathrm{Mg} / \mathrm{Ca}$ variations are $\sim 30.3 \%$ for newly grown chambers in culture (S 69), matching earlier findings for planktonic foraminifers (Sadekov et al. 2005; DueñasBohórquez et al. 2011). The intra-shell variability of single spot $\mathrm{Mg} / \mathrm{Ca}$ values within one foraminifer $(0.1-6.4$ $\mathrm{mmol} / \mathrm{mol}$ ) is an order of magnitude higher. Such high $\mathrm{Mg}$ / $\mathrm{Ca}$ intra-shell variations $(0.1-7 \mathrm{mmol} / \mathrm{mol})$ were also observed in the study by Jonkers et al. (2016) for $N$. pachyderma of the subpolar North Atlantic. While symbiont-bearing species tend to exhibit cyclic banding, alternating in high- and low $\mathrm{Mg} / \mathrm{Ca}$ bands, less $\mathrm{Mg} / \mathrm{Ca}$ variations throughout the entire shell, as well as less and broader $\mathrm{Mg} / \mathrm{Ca}$ bands are observed for symbiont-barren species (Sadekov et al. 2005), which is in agreement with our results (Fig. $4 \mathrm{~b}, \mathrm{c})$. However, high intra-shell variations need further explanations, as cultured foraminifers grow their chambers under controlled conditions with minor changes in temperature and constant salinity conditions. Further, foraminifers were not able to migrate in their culture jar similar to conditions in the sea ice with limited space, which would exclude vertical habitat migration and thus changes in calcification temperature by increasing water depth (Eggins et al. 2003; Sadekov et al. 2005; Spero et al. 2015). Therefore, we would rather suggest a strong biological control on $\mathrm{Mg}$ incorporation explaining the high intra-shell variability, which is in agreement with observations from Jonkers et al. (2016), who further related $\mathrm{Mg} / \mathrm{Ca}$ banding to chamber formation processes in N. pachyderma.

\section{$\mathrm{Sr} / \mathrm{Ca}$}

Our $\mathrm{Sr} / \mathrm{Ca}$ results $(\sim 1.37 \mathrm{mmol} / \mathrm{mol} \pm 0.05 \mathrm{SE})$ of chambers grown in situ before the onset of culture experiments are in agreement with previous findings: $\mathrm{Sr} / \mathrm{Ca}$ results of $N$. pachyderma (s) specimens collected from sediment traps in the West Antarctic Peninsula close to our sampling locality vary only on small scale throughout the year (1.37-1.40 $\mathrm{mmol} / \mathrm{mol}$ ) with peak values during the period of sea ice cover (Hendry et al. 2009). In addition, core-top samples from the North Atlantic revealed similar $\mathrm{Sr} / \mathrm{Ca}$ values of $1.39 \pm 0.02$ $\mathrm{mmol} / \mathrm{mol}$ for $N$. pachyderma (Elderfield et al. 2000). Nevertheless, average $\mathrm{Sr} / \mathrm{Ca}$ values $(1.66 \pm 0.09 \mathrm{mmol} / \mathrm{mol})$ of newly calcified chambers in the culture at a salinity of 69 , exceed all published values derived from specimens from the open ocean. Thus, Sr uptake into calcite shells cannot be solely dependent on seawater Sr/Ca (Elderfield et al. 2000). Previous studies have demonstrated that seawater calcite saturation influences calcite precipitation rates in foraminifers, 
which in turn also controls the $\mathrm{Sr}$ incorporation into calcite shells (Lea et al. 1999; Kisakürek et al. 2008; DueñasBohórquez et al. 2009). This is also known from inorganic calcite growth experiments, demonstrating higher Sr incorporation and an increasing partition coefficient $D_{\mathrm{Sr}}$ with enhanced calcite precipitation rates (e.g., Lorens 1981; Busenberg and Plummer 1989; Nehrke et al. 2007; Tang et al. 2008). Other environmental factors as temperature, salinity, or $\mathrm{pH}$ could further influence the calcite saturation state and growth rates indirectly, but only to a certain extent as these parameters co-vary (Lea et al. 1999; Elderfield et al. 2002; Kisakürek et al. 2008; Dissard et al. 2010). Further, culture and core-top studies reveal that $\mathrm{Sr} / \mathrm{Ca}$ incorporation increases slightly with temperature $\left(0.4-0.8 \% /{ }^{\circ} \mathrm{C}\right)$, salinity $(0.8-1.3 \pm 0.3 \% / \mathrm{S}$, salinity interval: $20-40)$, and $\mathrm{pH}(0.5-$ $1.0 \%$ per $0.1 \mathrm{pH}$ unit) for the planktic species G. bulloides, O. universa, T. sacculifer, G. ruber (white), and the benthic Ammonia tepida (Lea et al. 1999; Elderfield et al. 2000; Russell et al. 2004; Mortyn et al. 2005; Kisakürek et al. 2008; Dueñas-Bohórquez et al. 2009; Dissard et al. 2010). Although temperature and salinity have an insignificant effect on $\mathrm{Sr}$ incorporation in the aforementioned species (Elderfield et al. 2002; Kisakürek et al. 2008; Dueñas-Bohórquez et al. 2009), this effect should not be disregarded in extreme environments as our high salinity study shows. Moreover, according to our culture experiments, shell $\mathrm{Sr} / \mathrm{Ca}$ is more sensitive to abrupt salinity changes in colder waters than expected for $\mathrm{Mg}$ / Ca values (Fig. 6).

Differences in element incorporation (e.g., $\mathrm{Mg}^{2+}, \mathrm{Sr}^{2+}$ ) into foraminiferal calcite could be attributed to different pathways of ions to the site of calcification and due to differences in ionic strength, surface charge density, and ionic radii between trace elements despite substitution for $\mathrm{Ca}^{2+}$ in the $\mathrm{CaCO}_{3}$ lattice. While $\mathrm{Mg}^{2+}$ ions $(0.72 \AA)$ are smaller and $\mathrm{Sr}^{2+}$ ions $(1.13 \AA)$ are larger than $\mathrm{Ca}^{2+}$ ions $(0.99 \AA)$, these ions substitute for $\mathrm{Ca}$ at different sites in the calcite lattice (De Nooijer et al. 2014; Yoshimura et al. 2017). The partition coefficient for $\operatorname{Sr}\left(D_{\mathrm{Sr}}\right)$ in foraminiferal calcite is only 3 to 4 times higher than for inorganic calcite $(\sim 0.04)$, whereby $\mathrm{Mg}^{2+}$ incorporation is strongly biologically controlled and 5 to 10 times lower than in inorganic precipitated calcite (0.01) (Lorens 1981; Busenberg and Plummer 1989; Elderfield et al. 2002; Erez 2003; Nehrke et al. 2007; Dissard et al. 2010). The homogeneous distribution of $\mathrm{Sr} / \mathrm{Ca}$ in $N$. pachyderma compared with $\mathrm{Mg} / \mathrm{Ca}$, and the absence of cyclic banding throughout chamber wall cross sections (Fig. 4a) support the assumption that $\mathrm{Sr}^{2+}$ is most likely passively transported to the foraminiferal site of calcification (Lea et al. 1999; Elderfield et al. 2002; Kisakürek et al. 2008; Dissard et al. 2010).

\section{$\mathrm{Na} / \mathrm{Ca}$}

Average $\mathrm{Na} / \mathrm{Ca}$ values in cultured $N$. pachyderma (s) show a positive correlation with increasing salinities up to 69 (Fig. 6) and are within the range of previous studies, summarized in Fig. 7. $\mathrm{Na} / \mathrm{Ca}$ values of pre-grown chambers (N. pachyderma) before culturing follow the same slope of the regression line $(\sim$ $+0.1 \mathrm{mmol} / \mathrm{mol}$ per salinity unit) and are in agreement with $\mathrm{Na} / \mathrm{Ca}$ values of the symbiont-bearing species G. ruber (culture: Allen et al., 2016; core-tops: Mezger et al., 2018), and the benthic symbiont-barren species Ammonia tepida (Wit et al. 2013; Geerken et al. 2018) in the salinity interval of 30 to 40 (Fig. 7). Moreover, cultured N. pachyderma (s) specimens exhibit a lower inter-shell variability (SD: $12.9 \%$ ) of new calcified chambers ( $\mathrm{S} 69$ ) in comparison to $\mathrm{Mg} / \mathrm{Ca}$ variations (SD: $30.3 \%$ ) between single foraminifers. Such

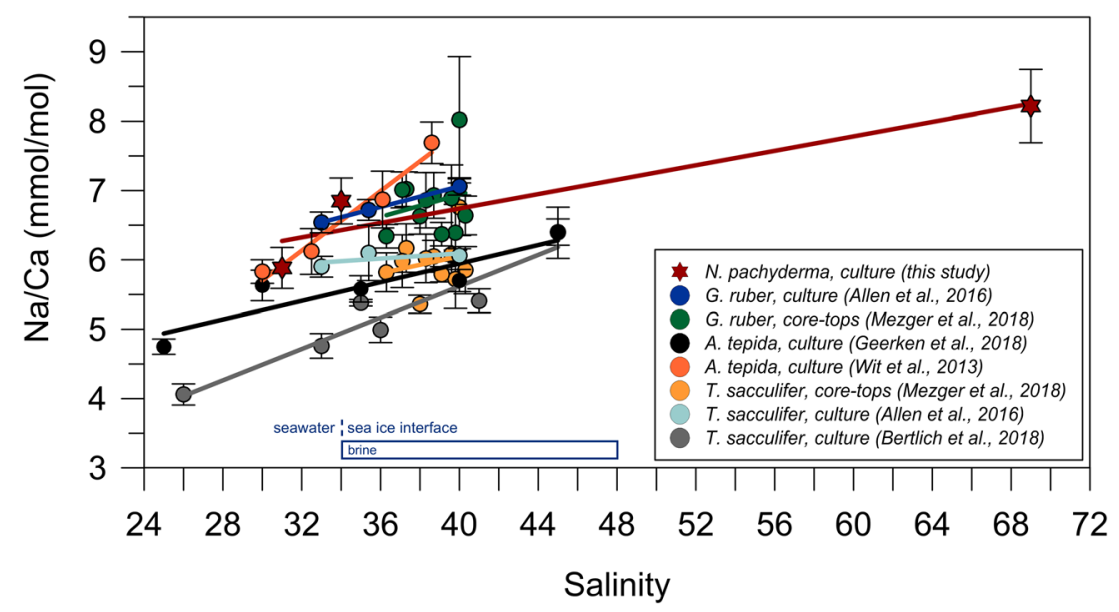

Fig. 7 Comparison of published foraminiferal $\mathrm{Na} / \mathrm{Ca}$ data sets in relation to seawater salinity. Average $\mathrm{Na} / \mathrm{Ca}$ values of cultured $N$. pachyderma (our study) are in agreement with previous findings and follow the same slope of regression line as shown for cultured G. ruber (pink) (Allen et al. 2016) and G. ruber (white) from core-top sediment samples (Mezger et al. 2018). Moreover, results of our study agree with $\mathrm{Na} / \mathrm{Ca}$ values of the benthic foraminifer A. tepida (salinity $\leq 36$; Wit et al. 2013), and show the same trend as A. tepida (Geerken et al., 2018) with a $\mathrm{Na} / \mathrm{Ca}$ offset of 1 $\mathrm{mmol} / \mathrm{mol}$ to our results. The blue horizontal error bar indicates the potential salinity range of pre-grown chambers (our study) at the seawater/ sea ice interface before foraminifers were placed in culture (S 34-48; WOA2013; Lemke 2014b; Tison et al. 2008) 
comparatively low $\mathrm{Na} / \mathrm{Ca}$ variability matches earlier findings by Bertlich et al. (2018) and Mezger et al. (2016) for symbiont-bearing species.

These new insights confirm the robustness of shell $\mathrm{Na} / \mathrm{Ca}$ as a potential proxy for sea surface salinities at higher latitudes. Although previous studies could show an insignificant temperature effect between a range of $19.5^{\circ} \mathrm{C}$ to $29.5^{\circ} \mathrm{C}$ on $\mathrm{Na}$ incorporation into symbiont-bearing species (Allen et al. 2016; Mezger et al. 2016; Bertlich et al. 2018), this needs further research due to the fact that $N$. pachyderma (s) can tolerate temperatures to $-4{ }^{\circ} \mathrm{C}$ (Spindler, 1996). In addition, the Na incorporation into symbiont-bearing species ( $G$. ruber, T. sacculifer: Allen et al. 2016) is not significantly influenced by changes in the carbonate chemistry $\left(\mathrm{pH},\left[\mathrm{CO}_{3}{ }^{2-}\right]\right.$, dissolved inorganic carbon), but has to be confirmed again for symbiont-barren species in a sea ice environment. Nevertheless, assuming salinity as the dominant controlling factor on $\mathrm{Na}$ incorporation in $N$. pachyderma, average $\mathrm{Na}$ / $\mathrm{Ca}$ values of individuals from the austral winter, trapped in sea ice, could thus reveal higher $\mathrm{Na} / \mathrm{Ca}$ values. Such higher $\mathrm{Na} / \mathrm{Ca}$ values in a sea ice environment could influence the interpretation of fossil records, which is further discussed in the following section.

\section{Implications for paleoenvironmental reconstructions}

Based on our culture experiments, we hypothesize that elevated shell $\mathrm{Mg} / \mathrm{Ca}, \mathrm{Sr} / \mathrm{Ca}$ and $\mathrm{Na} / \mathrm{Ca}$ values in $N$. pachyderma (s) specimens from high latitudes could result from sea ice formation at the time of calcification. We further suggest the application of a multi-proxy approach including the measurement of the foraminiferal oxygen isotopic signature. In the following we present evidence from the literature, underlining our observations and suggestions for a multi-proxy application.

The salinity of sea ice brines differs significantly from the pelagic ocean. Thus, chamber calcification within sea ice brine channels would carry a distinct proxy signature. The number of juvenile foraminifers trapped in the sea ice during its yearly formation is around 70 times higher per liter than in the underlying water column (Dieckmann et al. 1991). Consequently, under certain conditions, sea ice derived foraminifers may significantly contribute to the sedimentary record and thus potentially influence paleoenvironmental reconstructions.

This hypothesis is supported by shell $\mathrm{Mg} / \mathrm{Ca}$ and $\mathrm{Sr} / \mathrm{Ca}$ ratios from foraminifers collected from core-top sediments (e.g., Eggins et al. 2003; Meland et al. 2006; Hendry et al. 2009). $\mathrm{Mg} / \mathrm{Ca}$ results of $N$. pachyderma from the Nordic Seas (core-tops; Meland et al., 2006) do not fit to the $\mathrm{Mg} / \mathrm{Ca}$ to calcification temperature calibration curves provided by Nürnberg (1995) and Elderfield and Ganssen (2000), being $\sim 0.4 \mathrm{mmol} / \mathrm{mol}$ higher. Elevated values were attributed to changes in the seawater chemistry $\left(\left[\mathrm{CO}_{3}{ }^{2-}\right], \mathrm{pH}\right.$ and/or alkalinity, salinity) at times of partial sea ice cover during the Last Glacial Maximum (Meland et al. 2006), supporting our findings from high saline culture experiments. Moreover, Eggins et al. (2003) reported anomalously high $\mathrm{Mg} / \mathrm{Ca}$ values in N. pachyderma (s) from Prydz Bay, which in turn would result in unrealistic high calcification temperatures, even though this area was probably covered by sea ice during the Last Glacial Maximum at around 18.000 years before present. Eggins et al. (2003) proposed as one possible explanation that salinity changes are primarily controlling element incorporation over temperature.

In addition, the combination of planktonic foraminiferal $\mathrm{Sr} /$ $\mathrm{Ca}$ and $\delta^{18} \mathrm{O}$ allows to predict changes in seawater $\mathrm{Sr} / \mathrm{Ca}$ over glacial-interglacial cycles (Elderfield et al. 2000). The authors reported higher $\mathrm{Sr} / \mathrm{Ca}$ variations over time in $N$. pachyderma within the Last Glacial Maximum (increase of $\mathrm{Sr} / \mathrm{Ca}$ by $10 \%$ ) compared with other warm water planktonic species ( $\sim 5 \%$ ) (Elderfield et al. 2000). Thus, increased foraminiferal $\mathrm{Sr} / \mathrm{Ca}$ values could be attributed to the duration and/or extent of sea ice cover at that time. To support the assumption of a sea ice-covered paleo-environment causing elevated element ratios, the measurement of foraminiferal $\delta^{18} \mathrm{O}_{\text {foram }}$ would provide further evidence.

Besides the influence of temperature and salinity on element incorporation into calcite shells, both parameters influence the foraminiferal oxygen isotopic signature. In sea surface waters $(\mathrm{sw}), \delta^{18} \mathrm{O}_{\mathrm{sw}}$ and salinity are highly correlated (increase of $0.5 \%$ per salinity unit on global average) and influenced by evaporation (increase in salinity and $\delta^{18} \mathrm{O}_{\mathrm{sw}}$ ) and precipitation (decrease in salinity and $\delta^{18} \mathrm{O}_{\text {sw }}$ ) processes, resulting in lower values at high northern and southern latitudes (Gussone et al. 2004; Ravelo and Hillaire-Marcel 2007). This salinity to $\delta^{18} \mathrm{O}_{\mathrm{sw}}$ relationship further affects the stable oxygen isotope signature in foraminiferal calcite $\left(\delta^{18} \mathrm{O}_{\text {foram }}\right)$, which is influenced by the thermodynamic isotopic fractionation between $\delta^{18} \mathrm{O}_{\text {foram }}$ and $\delta^{18} \mathrm{O}_{\text {sw }}$ during calcite precipitation. The $\delta^{18} \mathrm{O}_{\text {foram }}$ values are inversely correlated to its calcification temperature (decrease of $\sim 0.2 \%$ o by an increase of $1{ }^{\circ} \mathrm{C}$ ), as foraminiferal calcite is in equilibrium with $\delta^{18} \mathrm{O}_{\mathrm{sw}}$ (Ravelo and Hillaire-Marcel 2007).

The duration of sea ice cover could lead to an isotopic offset in calcite shells, recording the temperature and $\delta^{18} \mathrm{O}_{\text {brine }}$ of the ambient environment. Due to ongoing sea ice formation, brines get more saline and isotopically lighter. Accordingly, the brine $\delta^{18} \mathrm{O}$ signature becomes increasingly depleted as the surrounding sea ice is enriched in ${ }^{18} \mathrm{O}$ (O'Neil 1968). The oxygen isotope fractionation from seawater to sea ice is around 1.003 (O’Neil 1968). Thus, the sea ice brines reveal $\delta{ }^{18} \mathrm{O}_{\text {brine }}$ values between $\sim-9 \%$ and $+0.5 \%$ and decrease with sea ice thickness towards the sea ice-seawater interface (Tison et al. 2008). 
Hendry et al. (2009) reported decreasing $\delta^{18} \mathrm{O}$ values from $\sim 3.2$ to $2.9 \%$ in $N$. pachyderma (s) at the time of sea ice cover of the West Antarctic Peninsula. The same trend is mentioned for N. pachyderma (s) in the Weddell Sea by Berberich (1996). Whereas $\delta^{18} \mathrm{O}_{\text {foram }}$ values of the summer population are expected to be around $3.9 \%$, a decreasing trend by $\sim 0.3$ $\% o$ is reported for the winter population, which is assumed to occur because the foraminifera were trapped in sea ice (Berberich 1996). This supports our hypothesis that foraminifers calcifying in the sea ice incorporate presumably lower $\delta^{18} \mathrm{O}$ values in their calcite shells with increasing brine salinities, causing the depletion of ${ }^{18} \mathrm{O}$ in the foraminiferal shells. With respect to paleo-reconstructions, the geochemical signature of foraminifers formed within sea ice would lead to the assumption and interpretation that affected foraminifers would have calcified at warmer temperatures due to lighter oxygen isotopes and higher trace element concentrations. Changes in the geochemical signature of $N$. pachyderma shells could be significant when considering the ability of chamber wall thickening up to salinities of 83 in culture. Previous studies have shown for neogloboquadrinid shells that the outer calcite layer is highly variable and could amount to $55 \%$ of the entire shell wall thickness (Jonkers et al. 2012; Fehrenbacher et al. 2017). Our data suggest a possible bias of $\mathrm{Mg} / \mathrm{Ca}, \mathrm{Sr} / \mathrm{Ca}, \mathrm{Na} /$ $\mathrm{Ca}$ (and $\delta^{18} \mathrm{O}$ ) of shells formed within sea ice, which could now explain previously unexplainable high $\mathrm{Mg} / \mathrm{Ca}$ or $\mathrm{Sr} / \mathrm{Ca}$ values in foraminiferal calcite at the time of the Last Glacial Maximum in regions where we would expect sea ice cover (see, e.g., Eggins et al. 2003, Meland et al. 2006; Hendry et al. 2009). However, additional culture experiments in comparison with sediment surface samples are essential to further constrain these initial observations.

\section{Conclusions}

This study presents new environmental insights on chamber calcification of the polar species $N$. pachyderma (s) under extreme culture conditions, akin to those expected in sea ice brines. Newly formed chambers were clearly identified in juvenile to pre-adult foraminifers $(\leq 150 \mu \mathrm{m})$ at culture conditions with $\mathrm{S} 30,31$, and 69 , whereas chamber wall thickening was even observed up to $\mathrm{S} 83$. Chamber thickening was in particular prominent for specimens at a later life-stage $(\geq 150$ $250 \mu \mathrm{m})$ in culture. Calcification within extreme culture conditions would imply that $N$. pachyderma specimens can tolerate high salinity gradients $\geq$ S 83 (and low temperatures), similar to conditions where individuals are captured in sea ice brine pockets during sea ice formation.

As the chemical composition and in particular the salinity of sea ice brines differs significantly from seawater in the pelagic ocean, chamber calcification within sea ice brines would carry a distinct proxy signature in relation to paleo- oceanographic reconstructions. Our electron microprobe based single foraminiferal element analysis showed elevated $\mathrm{Mg} / \mathrm{Ca}, \mathrm{Sr} / \mathrm{Ca}$, and $\mathrm{Na} / \mathrm{Ca}$ values of cultured $N$. pachyderma at higher salinities, whereas $\mathrm{Mg} / \mathrm{Ca}$ showed the weakest response to salinity changes in culture. For $N$. pachyderma, $\mathrm{Na} / \mathrm{Ca}$ values showed a statistically significant positive correlation with salinity changes (S 31-69) in culture, following the same slope of regression line as previously reported for cultured G. ruber (pink) and G. ruber (white) from core-top sediments (Allen et al. 2016; Mezger et al. 2018). Although the sea ice brine composition differs from seawater, it is likely that the salinity is the prime driver controlling $\mathrm{Na}$ incorporation into N. pachyderma specimens. Our conclusion is supported by previous studies that reported an insignificant effect of changes in temperature or in the carbonate chemistry (e.g., $\left.\mathrm{pH},\left[\mathrm{CO}_{3}{ }^{2-}\right]\right)$ on $\mathrm{Na}$ incorporation into symbiont-bearing species (G. ruber, T. sacculifer: Allen et al. 2016; Mezger et al. 2016; Bertlich et al. 2018), which requires further research for cold-water and symbiont-barren species. For $N$. pachyderma specimens cultured at high salinity (S 69), $\mathrm{Mg} / \mathrm{Ca}$ and $\mathrm{Sr} / \mathrm{Ca}$ values exceed values from fossil records (Hendry et al. 2009) and calibration studies (for Mg: e.g., Nürnberg 1995; Elderfield and Ganssen 2000). Multiple factors have additional control on foraminiferal $\mathrm{Mg} / \mathrm{Ca}$ incorporation; however, it is most likely that changes in salinity within brine channels could predominately control Mg incorporation over temperature and $\mathrm{pH}$ changes. Even though $\mathrm{Sr} / \mathrm{Ca}$ is homogenously distributed in cultured shells, higher salinities should not be neglected, as these could indirectly promote calcification processes, and further, the increase in $\mathrm{Sr} / \mathrm{Ca}$ (Lea et al. 1999; Elderfield et al. 2002; Kisakürek et al. 2008; Dissard et al. 2010). Based on our results, significant enrichments of $\mathrm{Na} /$ $\mathrm{Ca}, \mathrm{Sr} / \mathrm{Ca}, \mathrm{Mg} / \mathrm{Ca}$, and the hypothetical depletion of ${ }^{18} \mathrm{O}_{\text {foram }}$ would be expected in $N$. pachyderma present in regions with more sea ice cover, leading to anomalously high salinity and temperature estimates in paleo-reconstructions (cf. Eggins et al. 2003, Meland et al. 2006; Hendry et al. 2009). Hence, this study helps to explain inexplicable high trace element values in foraminiferal shells from polar environments based on the confirmed evidence of their survival and calcite formation in high salinity culture experiments.

Acknowledgments We thank Hans Kerp for the support and the provision of the fluorescence microscope, Maik Trogisch for accurate sample preparation, Beate Schmitte for support at the electron microprobe, and Stefan Rinnen for the Tof-SIMS measurements. We thank Christiane Uhlig for supporting foraminiferal culture experiments on board the $\mathrm{R} /$ $\mathrm{V}$ Polarstern and Gernot Nehrke for taking care of the experiments during the expedition ANT-XXIX/7 and Nina Keul for critical discussions. We would like to express our gratitude to three anonymous reviewers who helped to improve our manuscript. We also thank Gabriele UenzelmannNeben for the editorial handling.

Funding Open Access funding enabled and organized by Projekt DEAL. Participation of Nikolaus Gussone on the research expedition ANT- 
XXIX/6 was supported by a travel grant from SPP 1158 "Antarctic Research with comparative investigations in Arctic ice areas" of the Deutsche Forschungsgemeinschaft (DFG). During the time of manuscript preparation, Jacqueline Bertlich was funded by a Ph.D. fellowship of the Helmholtz Research School for Ocean System Science and Technology (HOSST) at GEOMAR Helmholtz Centre for Ocean Research Kiel (VHKO-601).

\section{Appendix 1}

Table 3 Trace element results of single spot measurements by the electron microprobe. Each value represents one spot on chamber wall cross sections of cultured $N$. pachyderma at different salinities and a constant temperature $\left(-1\right.$ to $\left.+2{ }^{\circ} \mathrm{C}\right)$. The final chamber $\mathrm{F}$ has been grown in culture. Chambers F-1 and F-2 have been grown prior to the
Data availability All data used in this study are presented in the manuscript and appendices. The sample material is archived at the Westfälische Wilhelms-Universität Münster (contact: nikolaus.gussone@unimuenster.de).

\section{Compliance with ethical standards}

Competing interests The authors declare that they have no conflict of interest.

culture experiments most likely at the sea surface (S 34) or at the sea ice interface (S 34-48) (WOA2013; Lemke 2014b; Tison et al. 2008). Average shell $\mathrm{Mg} / \mathrm{Ca}, \mathrm{Sr} / \mathrm{Ca}$, and $\mathrm{Na} / \mathrm{Ca}$ values are based on the standard error $\pm \mathrm{SE}(\sigma / \sqrt{ } n)$ and are shown in italic

Individual Chamber Salinity $\mathrm{Mg} / \mathrm{Ca}(\mathrm{mmol} / \mathrm{mol}) \quad$ Average $\pm \mathrm{SE} \quad \mathrm{Sr} / \mathrm{Ca}(\mathrm{mmol} / \mathrm{mol}) \quad$ Average $\pm \mathrm{SE} \quad \mathrm{Na} / \mathrm{Ca}(\mathrm{mmol} / \mathrm{mol}) \quad$ Average $\pm \mathrm{SE}$ foraminifer \#

\begin{tabular}{|c|c|c|c|c|c|c|c|c|}
\hline 1 & $\mathrm{~F}$ & 69 & 1.86 & $2.10 \pm 0.54$ & 1.12 & $1.61 \pm 0.16$ & 9.73 & $8.08 \pm 0.63$ \\
\hline 1 & $\mathrm{~F}$ & 69 & 1.03 & & 0.99 & & 6.14 & \\
\hline 1 & $\mathrm{~F}$ & 69 & - & & 1.47 & & 10.09 & \\
\hline 1 & $\mathrm{~F}$ & 69 & 4.83 & & 2.21 & & 9.62 & \\
\hline 1 & $\mathrm{~F}$ & 69 & 0.73 & & 1.68 & & 6.63 & \\
\hline 1 & $\mathrm{~F}$ & 69 & 1.02 & & 2.20 & & 7.37 & \\
\hline 1 & $\mathrm{~F}$ & 69 & 2.68 & & 1.83 & & 7.00 & \\
\hline 1 & $\mathrm{~F}$ & 69 & 2.57 & & 1.36 & & - & \\
\hline 1 & F-1 & 34 & 1.09 & $1.09 \pm 0.20$ & 1.76 & $1.45 \pm 0.12$ & 6.45 & $5.65 \pm 0.56$ \\
\hline 1 & F-1 & 34 & 1.13 & & 1.44 & & 3.73 & \\
\hline 1 & F-1 & 34 & 2.14 & & 1.80 & & 7.49 & \\
\hline 1 & F-1 & 34 & 1.05 & & 0.87 & & 7.25 & \\
\hline 1 & F-1 & 34 & 0.95 & & 1.34 & & 3.47 & \\
\hline 1 & F-1 & 34 & 0.24 & & 1.27 & & 6.81 & \\
\hline 1 & F-1 & 34 & 1.51 & & 1.86 & & 4.86 & \\
\hline 1 & F-1 & 34 & 0.65 & & 1.26 & & 5.13 & \\
\hline 1 & $\mathrm{~F}-2$ & 34 & 1.56 & $1.09 \pm 0.19$ & 1.79 & $1.41 \pm 0.25$ & 4.49 & $5.91 \pm 0.52$ \\
\hline 1 & $\mathrm{~F}-2$ & 34 & 0.88 & & 1.71 & & 5.92 & \\
\hline 1 & $\mathrm{~F}-2$ & 34 & 0.70 & & 1.42 & & 6.33 & \\
\hline 1 & $\mathrm{~F}-2$ & 34 & 1.22 & & 0.70 & & 6.91 & \\
\hline 2 & $\mathrm{~F}$ & 69 & 0.95 & $1.14 \pm 0.10$ & 1.66 & $1.89 \pm 0.18$ & 7.99 & $9.26 \pm 1.49$ \\
\hline 2 & $\mathrm{~F}$ & 69 & 1.30 & & 2.24 & & 7.58 & \\
\hline 2 & $\mathrm{~F}$ & 69 & 1.17 & & 1.77 & & 12.23 & \\
\hline 2 & F-1 & 34 & 0.30 & $1.10 \pm 0.46$ & 1.08 & $1.26 \pm 0.20$ & 10.96 & $8.18 \pm 1.18$ \\
\hline 2 & F-1 & 34 & 1.90 & & 1.86 & & 5.31 & \\
\hline 2 & F-1 & 34 & 1.11 & & 0.99 & & 7.58 & \\
\hline 2 & F-1 & 34 & - & & 1.12 & & 8.88 & \\
\hline 2 & $\mathrm{~F}-2$ & 34 & 0.92 & $1.27 \pm 0.30$ & 1.79 & $1.49 \pm 0.28$ & 10.36 & $8.13 \pm 0.80$ \\
\hline 2 & $\mathrm{~F}-2$ & 34 & 1.53 & & 2.02 & & 6.93 & \\
\hline 2 & $\mathrm{~F}-2$ & 34 & 0.45 & & 1.95 & & 8.61 & \\
\hline 2 & F-2 & 34 & 1.21 & & 1.09 & & 8.96 & \\
\hline 2 & $\mathrm{~F}-2$ & 34 & 2.23 & & 0.61 & & 5.80 & \\
\hline 3 & $\mathrm{~F}$ & 69 & 0.45 & $1.15 \pm 0.32$ & 1.77 & $1.79 \pm 0.15$ & 9.30 & $9.17 \pm 0.57$ \\
\hline 3 & $\mathrm{~F}$ & 69 & 0.94 & & 1.62 & & 7.25 & \\
\hline 3 & $\mathrm{~F}$ & 69 & 3.14 & & 1.06 & & 9.51 & \\
\hline 3 & $\mathrm{~F}$ & 69 & 1.72 & & 2.33 & & 11.38 & \\
\hline 3 & $\mathrm{~F}$ & 69 & 0.79 & & 1.81 & & 10.88 & \\
\hline 3 & $\mathrm{~F}$ & 69 & 0.47 & & 1.98 & & 8.77 & \\
\hline 3 & $\mathrm{~F}$ & 69 & 0.74 & & 1.47 & & 6.71 & \\
\hline 3 & $\mathrm{~F}$ & 69 & 0.91 & & 2.27 & & 9.55 & \\
\hline 3 & F-1 & 34 & 0.24 & $0.27 \pm 0.10$ & 1.21 & $1.22 \pm 0.09$ & 8.20 & $7.16 \pm 0.76$ \\
\hline 3 & F-1 & 34 & 0.10 & & 1.38 & & 7.58 & \\
\hline 3 & F-1 & 34 & 0.46 & & 1.07 & & 5.68 & \\
\hline 3 & $\mathrm{~F}-2$ & 34 & 1.60 & $0.81 \pm 0.19$ & 1.38 & $1.15 \pm 0.12$ & 5.24 & $6.33 \pm 0.84$ \\
\hline 3 & $\mathrm{~F}-2$ & 34 & 0.55 & & 1.11 & & 9.01 & \\
\hline
\end{tabular}


Table 3 (continued)

Individual Chamber Salinity $\mathrm{Mg} / \mathrm{Ca}(\mathrm{mmol} / \mathrm{mol}) \quad$ Average $\pm \mathrm{SE} \quad \mathrm{Sr} / \mathrm{Ca}(\mathrm{mmol} / \mathrm{mol}) \quad$ Average $\pm \mathrm{SE} \quad \mathrm{Na} / \mathrm{Ca}(\mathrm{mmol} / \mathrm{mol}) \quad \mathrm{Average} \pm \mathrm{SE}$ foraminifer \#

\begin{tabular}{|c|c|c|c|c|c|c|c|c|}
\hline 3 & $\mathrm{~F}-2$ & 34 & 0.54 & & 1.58 & & 5.29 & \\
\hline 3 & F-2 & 34 & 0.26 & & 1.15 & & 5.21 & \\
\hline 3 & $\mathrm{~F}-2$ & 34 & 0.93 & & 0.87 & & 8.89 & \\
\hline 3 & F-2 & 34 & 1.00 & & 0.80 & & 4.33 & \\
\hline 4 & $\mathrm{~F}$ & 69 & 1.93 & $1.20 \pm 0.12$ & 1.49 & $1.38 \pm 0.10$ & 7.26 & $8.23 \pm 0.43$ \\
\hline 4 & $\mathrm{~F}$ & 69 & 0.99 & & 1.98 & & 5.77 & \\
\hline 4 & $\mathrm{~F}$ & 69 & 0.44 & & 1.56 & & 9.92 & \\
\hline 4 & $\mathrm{~F}$ & 69 & 0.63 & & 2.47 & & 8.26 & \\
\hline 4 & $\mathrm{~F}$ & 69 & 0.60 & & 1.12 & & 5.68 & \\
\hline 4 & $\mathrm{~F}$ & 69 & 0.97 & & 0.40 & & 7.09 & \\
\hline 4 & $\mathrm{~F}$ & 69 & 0.70 & & 0.85 & & 8.37 & \\
\hline 4 & $\mathrm{~F}$ & 69 & 0.62 & & 1.39 & & 9.71 & \\
\hline 4 & $\mathrm{~F}$ & 69 & 0.16 & & 1.94 & & 5.38 & \\
\hline 4 & $\mathrm{~F}$ & 69 & 1.17 & & 1.70 & & 9.91 & \\
\hline 4 & $\mathrm{~F}$ & 69 & 1.16 & & 1.04 & & 10.03 & \\
\hline 4 & $\mathrm{~F}$ & 69 & 2.31 & & 0.51 & & 11.26 & \\
\hline 4 & $\mathrm{~F}$ & 69 & 1.50 & & 1.54 & & 9.30 & \\
\hline 4 & $\mathrm{~F}$ & 69 & 1.63 & & 1.40 & & 10.71 & \\
\hline 4 & $\mathrm{~F}$ & 69 & 2.04 & & 1.63 & & 4.50 & \\
\hline 4 & $\mathrm{~F}$ & 69 & 1.60 & & 1.87 & & 8.96 & \\
\hline 4 & $\mathrm{~F}$ & 69 & - & & 0.93 & & 5.04 & \\
\hline 4 & $\mathrm{~F}$ & 69 & 1.04 & & 2.18 & & 10.30 & \\
\hline 4 & $\mathrm{~F}$ & 69 & - & & 1.16 & & 8.23 & \\
\hline 4 & $\mathrm{~F}$ & 69 & 0.96 & & 0.97 & & 4.72 & \\
\hline 4 & $\mathrm{~F}$ & 69 & 1.22 & & 1.60 & & 9.56 & \\
\hline 4 & $\mathrm{~F}$ & 69 & 0.87 & & 1.07 & & 5.29 & \\
\hline 4 & $\mathrm{~F}$ & 69 & 2.28 & & 1.39 & & 9.13 & \\
\hline 4 & $\mathrm{~F}$ & 69 & 1.63 & & 1.34 & & 10.32 & \\
\hline 4 & $\mathrm{~F}$ & 69 & 0.69 & & 0.79 & & 11.49 & \\
\hline 4 & $\mathrm{~F}$ & 69 & 1.72 & & 1.47 & & 7.89 & \\
\hline 4 & F-1 & 34 & 1.09 & $1.70 \pm 0.14$ & 1.82 & $1.44 \pm 0.09$ & 7.08 & $6.83 \pm 0.31$ \\
\hline 4 & F-1 & 34 & 2.47 & & 1.64 & & 4.88 & \\
\hline 4 & F-1 & 34 & 1.73 & & 1.21 & & 6.74 & \\
\hline 4 & F-1 & 34 & 1.87 & & 0.49 & & 6.81 & \\
\hline 4 & F-1 & 34 & 1.50 & & 1.50 & & 8.67 & \\
\hline 4 & F-1 & 34 & 2.48 & & 0.73 & & 7.80 & \\
\hline 4 & F-1 & 34 & 2.65 & & 1.34 & & 5.29 & \\
\hline 4 & F-1 & 34 & 1.10 & & 0.97 & & 6.20 & \\
\hline 4 & F-1 & 34 & 0.91 & & 1.65 & & 7.28 & \\
\hline 4 & F-1 & 34 & 1.80 & & 1.44 & & 6.81 & \\
\hline 4 & F-1 & 34 & 3.76 & & 1.97 & & 6.18 & \\
\hline 4 & F-1 & 34 & 2.13 & & 1.20 & & 6.70 & \\
\hline 4 & F-1 & 34 & 1.45 & & 1.18 & & 5.63 & \\
\hline 4 & F-1 & 34 & 1.58 & & 1.81 & & 5.44 & \\
\hline 4 & F-1 & 34 & 1.89 & & 1.73 & & - & \\
\hline 4 & F-1 & 34 & 1.71 & & 1.73 & & 9.97 & \\
\hline 4 & F-1 & 34 & 1.72 & & 1.80 & & 8.54 & \\
\hline 4 & F-1 & 34 & 0.38 & & 1.42 & & 9.59 & \\
\hline 4 & F-1 & 34 & 0.66 & & 1.48 & & 6.69 & \\
\hline 4 & F-1 & 34 & 1.70 & & 1.05 & & 6.70 & \\
\hline 4 & F-1 & 34 & 1.56 & & 0.80 & & 5.61 & \\
\hline 4 & F-1 & 34 & 1.14 & & 2.43 & & 9.50 & \\
\hline 4 & F-1 & 34 & 1.77 & & 1.69 & & 5.62 & \\
\hline 5 & $\mathrm{~F}$ & 69 & 1.02 & $1.23 \pm 0.29$ & 1.95 & $1.52 \pm 0.44$ & 6.86 & $6.61 \pm 1.18$ \\
\hline 5 & $\mathrm{~F}$ & 69 & 0.23 & & 1.75 & & 7.62 & \\
\hline 5 & $\mathrm{~F}$ & 69 & 1.04 & & 1.31 & & 7.16 & \\
\hline 5 & $\mathrm{~F}$ & 69 & 0.61 & & 2.08 & & 3.30 & \\
\hline 5 & $\mathrm{~F}$ & 69 & 6.43 & & 1.19 & & 6.74 & \\
\hline 5 & F-1 & 34 & 2.07 & $1.86 \pm 1.15$ & 0.12 & $1.65 \pm 0.18$ & 5.83 & $6.34 \pm 0.78$ \\
\hline 5 & F-1 & 34 & 1.46 & & 1.58 & & 4.25 & \\
\hline 5 & F-1 & 34 & 0.90 & & 1.06 & & 10.85 & \\
\hline 5 & F-1 & 34 & 1.39 & & 2.65 & & 7.31 & \\
\hline 5 & F-1 & 34 & 0.34 & & 2.20 & & 4.82 & \\
\hline 6 & $\mathrm{~F}$ & 31 & 1.00 & $1.24 \pm 0.14$ & 1.45 & $1.87 \pm 0.18$ & 5.58 & $5.88 \pm 0.30$ \\
\hline 6 & $\mathrm{~F}$ & 31 & 1.51 & & 2.01 & & 5.89 & \\
\hline 6 & $\mathrm{~F}$ & 31 & 0.80 & & 2.08 & & 6.37 & \\
\hline 6 & $\mathrm{~F}$ & 31 & 0.93 & & 2.09 & & 6.66 & \\
\hline 6 & $\mathrm{~F}$ & 31 & - & & 1.36 & & 6.68 & \\
\hline
\end{tabular}


Table 3 (continued)

Individual Chamber Salinity $\mathrm{Mg} / \mathrm{Ca}(\mathrm{mmol} / \mathrm{mol}) \quad$ Average $\pm \mathrm{SE} \quad \mathrm{Sr} / \mathrm{Ca}(\mathrm{mmol} / \mathrm{mol}) \quad$ Average $\pm \mathrm{SE} \quad \mathrm{Na} / \mathrm{Ca}(\mathrm{mmol} / \mathrm{mol}) \quad$ Average $\pm \mathrm{SE}$ foraminifer \#

\begin{tabular}{|c|c|c|c|c|c|c|c|c|}
\hline 6 & $\mathrm{~F}$ & 31 & 1.07 & & 2.06 & & 5.92 & \\
\hline 6 & $\mathrm{~F}$ & 31 & 1.72 & & 2.72 & & - & \\
\hline 6 & $\mathrm{~F}$ & 31 & 1.68 & & 2.19 & & 5.90 & \\
\hline 6 & $\mathrm{~F}$ & 31 & - & & 0.87 & & 4.06 & \\
\hline 6 & F-1 & 34 & 1.46 & \multirow[t]{10}{*}{$1.77 \pm 0.20$} & 2.39 & $1.86 \pm 0.10$ & 7.42 & \multirow[t]{10}{*}{$8.46 \pm 0.75$} \\
\hline 6 & F-1 & 34 & 1.17 & & 2.01 & & 8.98 & \\
\hline 6 & F-1 & 34 & 1.66 & & 1.96 & & 8.98 & \\
\hline 6 & F-1 & 34 & 2.19 & & 1.70 & & 12.31 & \\
\hline 6 & F-1 & 34 & 0.97 & & 1.85 & & 5.04 & \\
\hline 6 & F-1 & 34 & 1.40 & & 1.19 & & 6.01 & \\
\hline 6 & $\mathrm{~F}-1$ & 34 & 2.91 & & 1.98 & & 10.37 & \\
\hline 6 & F-1 & 34 & 1.60 & & 1.54 & & 8.33 & \\
\hline 6 & F-1 & 34 & 1.71 & & 1.95 & & 11.11 & \\
\hline 6 & F-1 & 34 & 2.62 & & 2.05 & & 6.07 & \\
\hline 6 & $\mathrm{~F}-2$ & 34 & 1.59 & \multirow[t]{11}{*}{$1.59 \pm 0.13$} & 1.82 & $1.54 \pm 0.09$ & 5.63 & \multirow[t]{11}{*}{$7.34 \pm 0.51$} \\
\hline 6 & $\mathrm{~F}-2$ & 34 & 2.51 & & 1.49 & & 6.97 & \\
\hline 6 & $\mathrm{~F}-2$ & 34 & 1.36 & & 1.27 & & 8.13 & \\
\hline 6 & $\mathrm{~F}-2$ & 34 & 1.46 & & 1.23 & & 4.47 & \\
\hline 6 & $\mathrm{~F}-2$ & 34 & 1.93 & & 2.06 & & 10.46 & \\
\hline 6 & $\mathrm{~F}-2$ & 34 & 1.23 & & 1.65 & & 6.38 & \\
\hline 6 & $\mathrm{~F}-2$ & 34 & 0.99 & & 1.71 & & 6.24 & \\
\hline 6 & F-2 & 34 & 1.47 & & 1.00 & & 7.37 & \\
\hline 6 & $\mathrm{~F}-2$ & 34 & 1.69 & & 1.75 & & 9.16 & \\
\hline 6 & $\mathrm{~F}-2$ & 34 & 1.65 & & 1.40 & & 8.41 & \\
\hline 6 & $\mathrm{~F}-2$ & 34 & - & & 1.56 & & 7.54 & \\
\hline
\end{tabular}

\section{Appendix 2. Application of time-of-flight secondary ion mass spectrometry}

Some cultured foraminifer shells were additionally measured by Time-of-Flight Secondary Ion Mass Spectrometry (ToFSIMS) as independent control of the results obtained by the electron microprobe analysis.

Selected sample mounts prepared for electron microprobe analyses were also used for element analysis by ToF-SIMS, as plane surfaces are essential for high-count yields and to avoid shading effects. Analyses of shell $\mathrm{Mg} / \mathrm{Ca}, \mathrm{Na} / \mathrm{Ca}, \mathrm{Sr} / \mathrm{Ca}$ ratios were performed at the Physikalisches Institut, Universität
Münster on a custom-built ToF-SIMS instrument that is largely equivalent to the ToF-SIMS IV (ION-TOF GmbH). Element concentrations were analyzed using the isotopes ${ }^{24} \mathrm{Mg},{ }^{25} \mathrm{Mg},{ }^{23} \mathrm{Na},{ }^{43} \mathrm{Ca},{ }^{44} \mathrm{Ca},{ }^{87} \mathrm{Sr}$, and ${ }^{88} \mathrm{Sr}$. The analyses were performed using a liquid metal ion source with a $25 \mathrm{keV}$ $\mathrm{Bi}_{3}{ }^{+}$ion beam operated at primary energy of $25 \mathrm{keV}$, and the ion distribution images were taken in the dual-beam mode. The primary ion current was $0.1 \mathrm{pA}$ and the integration time was set to $100 \mu \mathrm{s}$. Prior to analysis, the sample surface was cleaned by sputtering with argon ions (accelerated with $6 \mathrm{keV}$ ) for 2 -s and 0.5 -s idle time
Table 4 Trace element values of cultured N. pachyderma (s), measured by the ToF-SIMS. All values are given in counts per second (cps) and the error is based on the standard deviation (SD). Chamber $\mathrm{F}$ is newly formed during the experiments within a salinity of 31 and 69 . Preceding chambers (F-1, F-2) are grown in the natural habitat at an approximate seawater salinity of 34 or at the sea ice interface (S 34-48) (WOA2013; Lemke 2014b; Tison et al. 2008)

\begin{tabular}{llllll}
\hline $\begin{array}{l}\text { Individual } \\
\text { foraminifer } \#\end{array}$ & Chamber & Salinity & $\begin{array}{l}\mathrm{Mg} / \mathrm{Ca}(\mathrm{cps} / \mathrm{cps}) \times \\
10^{-2} \pm \mathrm{SD}\end{array}$ & $\begin{array}{l}\mathrm{Sr} / \mathrm{Ca}(\mathrm{cps} / \mathrm{cps}) \times \\
10^{-2} \pm \mathrm{SD}\end{array}$ & $\begin{array}{l}\mathrm{Na} / \mathrm{Ca}(\mathrm{cps} / \mathrm{cps}) \\
\pm \mathrm{SD}\end{array}$ \\
\hline 1 & $\mathrm{~F}$ & 69 & $0.25 \pm 0.02$ & $0.07 \pm 0.01$ & $0.21 \pm 0.12$ \\
1 & $\mathrm{~F}-1$ & 34 & $0.06 \pm 0.01$ & $0.07 \pm 0.004$ & $0.11 \pm 0.03$ \\
1 & $\mathrm{~F}-2$ & 34 & $0.08 \pm 0.07$ & $0.06 \pm 0.002$ & $0.14 \pm 0.05$ \\
3 & $\mathrm{~F}$ & 69 & $0.41 \pm 0.01$ & $0.07 \pm 0.003$ & $0.12 \pm 0.04$ \\
3 & $\mathrm{~F}-1$ & 34 & $0.06 \pm 0.002$ & $0.06 \pm 0.002$ & $0.14 \pm 0.03$ \\
3 & $\mathrm{~F}-2$ & 34 & $0.07 \pm 0.001$ & $0.06 \pm 0.001$ & $0.19 \pm 0.03$ \\
4 & $\mathrm{~F}$ & 69 & $0.26 \pm 0.004$ & $0.07 \pm 0.002$ & $0.15 \pm 0.03$ \\
4 & $\mathrm{~F}-1$ & 34 & $0.36 \pm 0.005$ & $0.06 \pm 0.002$ & $0.12 \pm 0.03$ \\
4 & $\mathrm{~F}-2$ & 34 & $0.23 \pm 0.002$ & $0.07 \pm 0.001$ & $0.14 \pm 0.02$ \\
6 & $\mathrm{~F}$ & 31 & $0.64 \pm 0.04$ & $0.09 \pm 0.003$ & $0.11 \pm 0.04$ \\
6 & $\mathrm{~F}-1$ & 34 & $0.41 \pm 0.08$ & $0.09 \pm 0.01$ & $0.12 \pm 0.02$ \\
6 & $\mathrm{~F}-2$ & 34 & $0.38 \pm 0.13$ & $0.09 \pm 0.01$ & $0.15 \pm 0.07$ \\
\hline
\end{tabular}



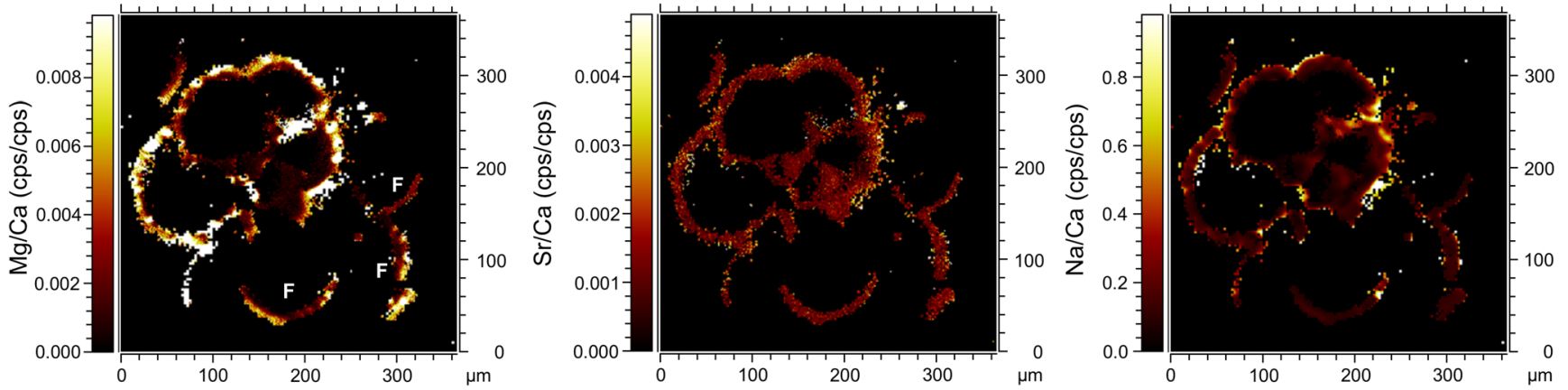

Fig. 8 Example of qualitative ToF-SIMS element distribution maps, showing chamber wall cross sections of cultured N. pachyderma (s). Element ratios are presented in counts per second (cps). The foraminifer

shown here was cultured at a salinity of 31 and formed a new chamber $(F)$ during the experiments
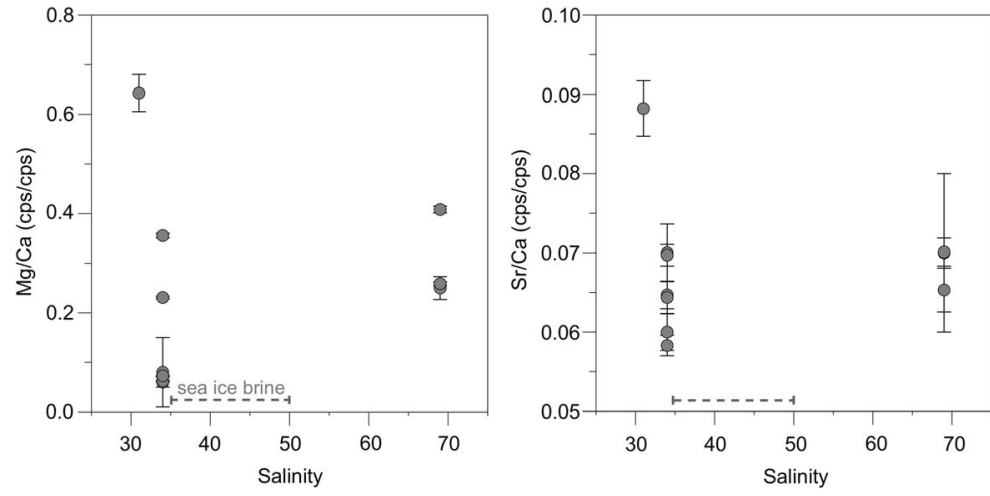

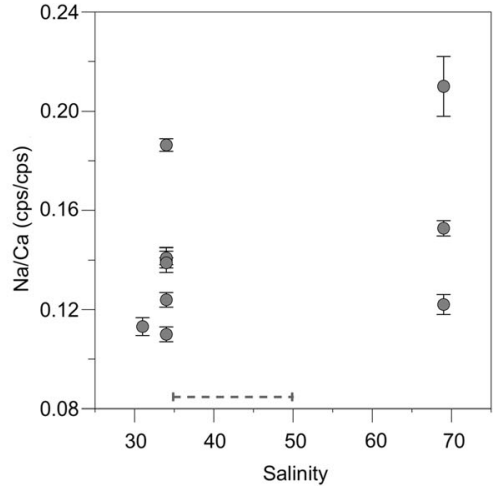

Single values are given in Table B. Trace element results from ToFSIMS measurements are comparable with electron microprobe results (Fig. 6) and show the same trend with increasing salinity. Shell $\mathrm{Mg} / \mathrm{Ca}$ and $\mathrm{Sr} / \mathrm{Ca}$ values at experiment S 31 (measured by ToF-SIMS) are exceptionally high compared with electron microprobe results, which may be the result of intra-shell variability within chambers, and minor changes in the element composition due to the fact that it is not possible to measure the exact spot twice
Open Access This article is licensed under a Creative Commons Attribution 4.0 International License, which permits use, sharing, adaptation, distribution and reproduction in any medium or format, as long as you give appropriate credit to the original author(s) and the source, provide a link to the Creative Commons licence, and indicate if changes were made. The images or other third party material in this article are included in the article's Creative Commons licence, unless indicated otherwise in a credit line to the material. If material is not included in the article's Creative Commons licence and your intended use is not permitted by statutory regulation or exceeds the permitted use, you will need to obtain permission directly from the copyright holder. To view a copy of this licence, visit http://creativecommons.org/licenses/by/4.0/.

\section{References}

Allen KA, Hönisch B, Eggins SM, Haynes LL, Rosenthal Y, Yu J (2016) Trace element proxies for surface ocean conditions: a synthesis of culture calibrations with planktic foraminifera. Geochim Cosmochim Acta 193:197-221. https://doi.org/10.1016/j.gca.2016.08.015
Anand P, Elderfield H, Conte MH (2003) Calibration of Mg/Ca thermometry in planktonic foraminifera from a sediment trap time series. Paleoceanography 18:n/a-n/a. https://doi.org/10.1029/ 2002pa000846

Arbuszewski J, deMenocal P, Kaplan A, Farmer EC (2010) On the fidelity of shell-derived $\delta^{18} \mathrm{O}_{\text {seawater }}$ estimates. Earth Planet Sci Lett 300: 185-196. https://doi.org/10.1016/j.epsl.2010.10.035

Barker S, Greaves M, Elderfield H (2003) A study of cleaning procedures used for foraminiferal $\mathrm{Mg} / \mathrm{Ca}$ paleothermometry. Geochem Geophys Geosyst 4:1-20. https://doi.org/10.1029/2003GC000559

Bartsch A (1989) Sea ice algae of the Weddell Sea (Antarctica): species composition, biomass, and ecophysiology of selected species. Ber Polarforsch 63:1-110

Bentov S, Brownlee C, Erez J (2009) The role of seawater endocytosis in the biomineralization process in calcareous foraminifera. Proc Natl Acad Sci U S A 106:21500-21504. https://doi.org/10.1073/pnas. 0906636106

Bentov S, Erez J (2005) Novel observations on biomineralization processes in foraminifera and implications for $\mathrm{Mg} / \mathrm{Ca}$ ratio in the shells. Geology 33:841-844. https://doi.org/10.1130/G21800.1

Berberich D (1996) Die planktische Foraminifere Neogloboquadrina pachyderma (Ehrenberg) im Weddellmeer, Antarktis. Dissertation, 
Alfred-Wegener-Institut für Polar- und Meeresforschung Bremerhaven. Berichte zur Polar- und Meeresforschung 195:2-198

Bergami C, Capotondi L, Langone L, Giglio F, Ravaioli M (2009) Distribution of living planktonic foraminifera in the Ross Sea and the Pacific sector of the Southern Ocean (Antarctica). Mar Micropaleontol 73:37-48. https://doi.org/10.1016/j.marmicro. 2009.06.007

Bernhard JM, Blanks JK, Hintz CJ, Chandler GT (2004) Use of the fluorescent calcite marker calcein to label foraminiferal tests. J Foraminifer Res 34:96-101. https://doi.org/10.2113/0340096

Bertlich J, Nürnberg D, Hathorne EC, de Nooijer LJ, Mezger EM, Kienast M, Nordhausen S, Reichart GJ, Schönfeld J, Bijma J (2018) Salinity control on Na incorporation into calcite tests of the planktonic foraminifera Trilobatus sacculifer - Evidence from culture experiments and surface sediments. Biogeosciences 15:59916018. https://doi.org/10.5194/bg-15-5991-2018

Bijma J, Faber W, Hemleben C (1990) Temperature and salinity limits for growth and survival of some planktonic foraminifers in laboratory cultures. J Foraminifer Res 20:95-116. https://doi.org/10.2113/ gsjfr.20.2.95

Buinitsky VK (1977) Organic life in sea ice. In: Dunbar MJ (ed) Polar Oceans, Arctic Institute of North America, pp 301-306

Busenberg E, Plummer LN (1989) Thermodynamics of magnesian calcite solid-solutions at $25^{\circ} \mathrm{C}$ and $1 \mathrm{~atm}$ total pressure. Geochim Cosmochim Acta 53:1189-1208. https://doi.org/10.1016/00167037(89)90056-2

De Nooijer LJ, Spero HJ, Erez J et al (2014) Biomineralization in perforate foraminifera. Earth-Sci Rev 135:48-58. https://doi.org/10.1016/ j.earscirev.2014.03.013

De Nooijer LJ, Toyofuku T, Kitazato H (2009) Foraminifera promote calcification by elevating their intracellular $\mathrm{pH}$. Proc Natl Acad Sci U S A 106:15374-15378. https://doi.org/10.1073/pnas.0904306106

Dieckmann GS, Spindler M, Lange MA, Ackley SF, Eicken H (1991) Antarctic sea ice: a habitat for the foraminifer Neogloboquadrina pachyderma. J Foraminifer Res 21:182-189. https://doi.org/10. 2113/gsjfr.21.2.182

Dissard D, Nehrke G, Reichart GJ, Bijma J (2010) The impact of salinity on the $\mathrm{Mg} / \mathrm{Ca}$ and $\mathrm{Sr} / \mathrm{Ca}$ ratio in the benthic foraminifera Ammonia tepida: results from culture experiments. Geochim Cosmochim Acta 74:928-940. https://doi.org/10.1016/j.gca.2009.10.040

Dissard D, Nehrke G, Reichart GJ, Nouet J, Bijma J (2009) Effect of the fluorescent indicator calcein on $\mathrm{Mg}$ and $\mathrm{Sr}$ incorporation into foraminiferal calcite. Geochem Geophys Geosyst 10:1-13. https://doi. org/10.1029/2009GC002417

Dueñas-Bohórquez A, da Rocha RE, Kuroyanagi A, Bijma J, Reichart GJ (2009) Effect of salinity and seawater calcite saturation state on $\mathrm{Mg}$ and $\mathrm{Sr}$ incorporation in cultured planktonic foraminifera. Mar Micropaleontol 73:178-189. https://doi.org/10.1016/j.marmicro. 2009.09.002

Dueñas-Bohórquez A, da Rocha RE, Kuroyanagi A, de Nooijer LJ, Bijma J, Reichart GJ (2011) Interindividual variability and ontogenetic effects on $\mathrm{Mg}$ and $\mathrm{Sr}$ incorporation in the planktonic foraminifer Globigerinoides sacculifer. Geochim Cosmochim Acta 75:520 532. https://doi.org/10.1016/j.gca.2010.10.006

Eggins S, De Deckker P, Marshall J (2003) Mg/Ca variation in planktonic foraminifera tests: implications for reconstructing palaeo-seawater temperature and habitat migration. Earth Planet Sci Lett 212:291306. https://doi.org/10.1016/S0012-821X(03)00283-8

Eggins SM, Sadekov A, De Deckker P (2004) Modulation and daily banding of $\mathrm{Mg} / \mathrm{Ca}$ in Orbulina universa tests by symbiont photosynthesis and respiration: a complication for seawater thermometry? Earth Planet Sci Lett 225:411-419. https://doi.org/10.1016/j.epsl. 2004.06.019

Elderfield H, Cooper M, Ganssen G (2000) Sr/Ca in multiple species of planktonic foraminifera: implications for reconstructions of seawater $\mathrm{Sr} / \mathrm{Ca}$. Geochem Geophys Geosyst 1. https://doi.org/10. 1029/1999GC000031

Elderfield H, Ganssen G (2000) Past temperature and $\delta^{18} \mathrm{O}$ of surface ocean waters inferred from foraminiferal $\mathrm{Mg} / \mathrm{Ca}$ ratios. Nature 405:442-445. https://doi.org/10.1038/35013033

Elderfield H, Vautravers M, Cooper M (2002) The relationship between shell size and $\mathrm{Mg} / \mathrm{Ca}, \mathrm{Sr} / \mathrm{Ca}, \delta^{18} \mathrm{O}$, and $\delta^{13} \mathrm{C}$ of species of planktonic foraminifera. Geochem Geophys Geosyst 3:1-13. https://doi.org/10. 1029/2001GC000194

Erez J (2003) The source of ions for biomineralization in Foraminifera and their implications for paleoceanographic proxies. Rev Mineral Geochem 54:115-149. https://doi.org/10.2113/0540115

Evans D, Brierley C, Raymo ME et al (2016) Planktic foraminifera shell chemistry response to seawater chemistry: Pliocene-Pleistocene seawater $\mathrm{Mg} / \mathrm{Ca}$, temperature and sea level change. Earth Planet Sci Lett 438:139-148. https://doi.org/10.1016/j.eps1.2016.01.013

Fehrenbacher JS, Russell AD, Davis CV, Gagnon AC, Spero HJ, Cliff JB, Zhu Z, Martin P (2017) Link between light-triggered Mgbanding and chamber formation in the planktic foraminifera Neogloboquadrina dutertrei. Nat Commun 8:1-10. https://doi.org/ 10.1038/ncomms 15441

Fox E, Meyer E, Panasiak N, Taylor AR (2018) Calcein staining as a tool to investigate coccolithophore calcification. Front Mar Sci 5:326

Geerken E, Jan De Nooijer L, Van DIjk I, Reichart GJ (2018) Impact of salinity on element incorporation in two benthic foraminiferal species with contrasting magnesium contents. Biogeosciences 15: 2205-2218. https://doi.org/10.5194/bg-15-2205-2018

Gray WR, Evans D (2019) Nonthermal influences on $\mathrm{Mg} / \mathrm{Ca}$ in planktonic Foraminifera: a review of culture studies and application to the last glacial maximum. Paleoceanogr Paleoclimatol 34:306-315. https://doi.org/10.1029/2018PA003517

Gray WR, Weldeab S, Lea DW, Rosenthal Y, Gruber N, Donner B, Fischer G (2018) The effects of temperature, salinity, and the carbonate system on $\mathrm{Mg} / \mathrm{Ca}$ in Globigerinoides ruber (white): a global sediment trap calibration. Earth Planet Sci Lett 482:607-620. https:// doi.org/10.1016/j.eps1.2017.11.026

Gussone N, Eisenhauer A, Tiedemann R, Haug GH, Heuser A, Bock B, Nägler TF, Müller A (2004) Reconstruction of Caribbean Sea surface temperature and salinity fluctuations in response to the Pliocene closure of the Central American Gateway and radiative forcing, using $\delta^{44 / 40} \mathrm{Ca}, \delta^{18} \mathrm{O}$ and $\mathrm{Mg} / \mathrm{Ca}$ ratios. Earth Planet Sci Lett 227: 201-214. https://doi.org/10.1016/j.epsl.2004.09.004

Gussone N, Friedrich O (2018) Cretaceous calcareous dinoflagellate cysts as recorder of $\delta^{44 / 40} \mathrm{Ca}_{\text {seawater }}$ and paleo-temperature using $\mathrm{Sr} / \mathrm{Ca}$ thermometry. Chem Geol 488:138-148. https://doi.org/10. 1016/j.chemgeo.2018.04.020

Gussone N, Zonneveld K, Kuhnert H (2010) Minor element and Ca isotope composition of calcareous dinoflagellate cysts of cultured Thoracosphaera heimii. Earth Planet Sci Lett 289:180-188. https:// doi.org/10.1016/j.epsl.2009.11.006

Hendry KR, Rickaby REM, Meredith MP, Elderfield H (2009) Controls on stable isotope and trace metal uptake in Neogloboquadrina pachyderma (sinistral) from an Antarctic sea-ice environment. Earth Planet Sci Lett 278:67-77. https://doi.org/10.1016/j.epsl. 2008.11.026

Hönisch B, Allen KA, Lea DW, Spero HJ, Eggins SM, Arbuszewski J, deMenocal P, Rosenthal Y, Russell AD, Elderfield H (2013) The influence of salinity on $\mathrm{Mg} / \mathrm{Ca}$ in planktic foraminifers - Evidence from cultures, core-top sediments and complementary $\delta^{18} \mathrm{O}$. Geochim Cosmochim Acta 121:196-213. https://doi.org/10.1016/ j.gca.2013.07.028

Huguet C, Schimmelmann A, Thunell R et al (2007) A study of the TEX86 paleothermometer in the water column and sediments of the Santa Barbara Basin, California. Paleoceanography 22(3). https://doi.org/10.1029/2006PA001310 
Jonkers L, Buse B, Brummer GJA, Hall IR (2016) Chamber formation leads to $\mathrm{Mg} / \mathrm{Ca}$ banding in the planktonic foraminifer Neogloboquadrina pachyderma. Earth Planet Sci Lett 451:177184. https://doi.org/10.1016/j.epsl.2016.07.030

Jonkers L, De Nooijer LJ, Reichart GJ et al (2012) Encrustation and trace element composition of Neogloboquadrina dutertrei assessed from single chamber analyses implications for paleotemperature estimates. Biogeosciences 9:4851-4860. https://doi.org/10.5194/bg-94851-2012

Jonkers L, Jiménez-Amat P, Mortyn PG, Brummer GJA (2013) Seasonal $\mathrm{Mg} / \mathrm{Ca}$ variability of $N$. pachyderma (s) and G. bulloides: implications for seawater temperature reconstruction. Earth Planet Sci Lett 376:137-144. https://doi.org/10.1016/j.epsl.2013.06.019

Kisakürek B, Eisenhauer A, Böhm F et al (2008) Controls on shell Mg/Ca and $\mathrm{Sr} / \mathrm{Ca}$ in cultured planktonic foraminiferan, Globigerinoides ruber (white). Earth Planet Sci Lett 273:260-269. https://doi.org/ 10.1016/j.epsl.2008.06.026

Kurtarkar SR, Saraswat R, Nigam R, Banerjee B, Mallick R, Naik DK, Singh DP (2015) Assessing the effect of calcein incorporation on physiological processes of benthic foraminifera. Mar Micropaleontol 114:36-45. https://doi.org/10.1016/j.marmicro. 2014.10.001

Lea DW, Mashiotta TA, Spero HJ (1999) Controls on magnesium and strontium uptake in planktonic foraminifera determined by live culturing. Geochim Cosmochim Acta 63:2369-2379. https://doi.org/ 10.1016/S0016-7037(99)00197-0

Lemke P (2014a) Station list and links to master tracks in different resolutions of POLARSTERN cruise ANT-XXIX/6, Cape Town - Punta Arenas, 2013-06-08 - 2013-08-12, Alfred Wegener Institute, Helmholtz Centre for Polar and Marine Research, Bremerhaven, PANGAEA. https://doi.org/10.1594/PANGAEA.829622

Lemke P (2014b) The expedition of the research vessel "Polarstern" to the Antarctic in 2013 (ANT-XXIX/6). Berichte zur Polar- und Meeresforschung $=$ Reports on polar and marine research, Bremerhaven, Alfred Wegener Institute for Polar Marine Research 679:154. https://doi.org/10.2312/BzPM 06792014

Lorens RB (1981) Sr, Cd, Mn and Co distribution coefficients in calcite as a function of calcite precipitation rate. Geochim Cosmochim Acta 45:553-561. https://doi.org/10.1016/0016-7037(81)90188-5

Meland MY, Jansen E, Elderfield H, Dokken TM, Olsen A, Bellerby RGJ (2006) $\mathrm{Mg} / \mathrm{Ca}$ ratios in the planktonic foraminifer Neogloboquadrina pachyderma (sinistral) in the northern North Atlantic/Nordic Seas. Geochem Geophys Geosyst 7. https://doi. org/10.1029/2005GC001078

Mezger EM, de Nooijer LJ, Boer W et al (2016) Salinity controls on Na incorporation in Red Sea planktonic foraminifera. Paleoceanography 31:1562-1582. https://doi.org/10.1002/ 2016PA003052

Mezger EM, de Nooijer LJ, Siccha M et al (2018) Taphonomic and ontogenetic effects on $\mathrm{Na} / \mathrm{Ca}$ and $\mathrm{Mg} / \mathrm{Ca}$ in spinose planktonic Foraminifera from the Red Sea. Geochem Geophys Geosyst 19: 4174-4194. https://doi.org/10.1029/2018GC007852

Mortyn PG, Elderfield H, Anand P, Greaves M (2005) An evaluation of controls on planktonic foraminiferal $\mathrm{Sr} / \mathrm{Ca}$ : comparison of water column and core-top data from a North Atlantic transect. Geochem Geophys Geosyst 6. https://doi.org/10.1029/2005GC001047

Nehrke G, Reichart GJ, Van Cappellen P et al (2007) Dependence of calcite growth rate and $\mathrm{Sr}$ partitioning on solution stoichiometry: non-Kossel crystal growth. Geochim Cosmochim Acta 71:2240 2249. https://doi.org/10.1016/j.gca.2007.02.002

Nürnberg D (1995) Magnesium in tests of Neogloboquadrina pachyderma sinistral from high northern and southern latitudes. J Foraminifer Res 25:350-368. https://doi.org/10.2113/gsjfr.25.4.350

Nürnberg D (2000) Taking the temperature of Past Ocean surfaces. Science 289:1698 LP-699. https://doi.org/10.1126/science.289. 5485.1698
Nürnberg D, Bijma J, Hemleben C (1996) Assessing the reliability of magnesium in foraminiferal calcite as a proxy for water mass temperatures. Geochim Cosmochim Acta 60:803-814. https://doi.org/ 10.1016/0016-7037(95)00446-7

O'Neil JR (1968) Hydrogen and oxygen isotope fractionation between ice and water. J Phys Chem 72:3683-3684. https://doi.org/10.1021/ j100856a060

Papadimitriou S, Thomas DN, Kennedy H, Haas C, Kuosa H, Krell A, Dieckmann GS (2007) Biogeochemical composition of natural sea ice brines from the Weddell Sea during early austral summer. Limnol Oceanogr 52:1809-1823. https://doi.org/10.4319/lo.2007. 52.5.1809

Ravelo AC, Hillaire-Marcel C (2007) Chapter Eighteen: The use of oxygen and carbon isotopes of Foraminifera in paleoceanography. Dev Mar Geol 1:735-764. https://doi.org/10.1016/S1572-5480(07) 01023-8

Regenberg M, Nürnberg D, Steph S et al (2006) Assessing the effect of dissolution on planktonic foraminiferal $\mathrm{Mg} / \mathrm{Ca}$ ratios: Evidence from Caribbean core tops. Geochemistry Geophys Geosystems 7. https://doi.org/10.1029/2005GC001019

Regenberg M, Steph S, Nürnberg D, Tiedemann R, Garbe-Schönberg D (2009) Calibrating $\mathrm{Mg} / \mathrm{Ca}$ ratios of multiple planktonic foraminiferal species with $\delta 18 \mathrm{O}$-calcification temperatures: paleothermometry for the upper water column. Earth Planet Sci Lett 278:324-336. https://doi.org/10.1016/j.epsl.2008.12.019

Rohling EJ, Bigg GR (1998) Paleosalinity and $\delta^{18} \mathrm{O}$ : A critical assessment. J Geophys Res Ocean 103:1307-1318. https://doi.org/ 10.1029/97JC01047

Rosenthal Y, Lohmann GP, Lohmann KC, Sherrell RM (2000) Incorporation and preservation of $\mathrm{Mg}$ in Globigerinoides sacculifer: Implications for reconstructing the temperature and ${ }^{18} \mathrm{O} /{ }^{16} \mathrm{O}$ of seawater. Paleoceanography 15:135-145. https://doi.org/10.1029/ 1999PA000415

Russell AD, Hönisch B, Spero HJ, Lea DW (2004) Effects of seawater carbonate ion concentration and temperature on shell $\mathrm{U}, \mathrm{Mg}$, and $\mathrm{Sr}$ in cultured planktonic foraminifera. Geochim Cosmochim Acta 68: 4347-4361. https://doi.org/10.1016/j.gca.2004.03.013

Sadekov AY, Eggins SM, De Deckker P (2005) Characterization of Mg/ $\mathrm{Ca}$ distributions in planktonic foraminifera species by electron microprobe mapping. Geochem Geophys Geosyst 6. https://doi.org/ 10.1029/2005GC000973

Sanyal A, Hemming NG, Broecker WS et al (1996) Oceanic pH control on the boron isotopic composition of foraminifera: Evidence from culture experiments. Paleoceanography 11:513-517. https://doi.org/ 10.1029/96PA01858

Schlitzer R (2015) Ocean Data View. http://odv.awi.de.

Schouten S, Hopmans EC, Schefuß E, Sinninghe Damsté JS (2002) Distributional variations in marine crenarchaeotal membrane lipids: a new tool for reconstructing ancient sea water temperatures? Earth Planet Sci Lett 204:265-274. https://doi.org/https://doi.org/10.1016/ S0012-821X(02)00979-2

Spero HJ, Eggins SM, Russell AD, Vetter L, Kilburn MR, Hönisch B (2015) Timing and mechanism for intratest $\mathrm{Mg} / \mathrm{Ca}$ variability in a living planktic foraminifer. Earth Planet Sci Lett 409:32-42. https:// doi.org/10.1016/j.eps1.2014.10.030

Spindler M (1996) On the salinity tolerance of the planktonic foraminifer Neogloboquadrina pachyderma from the Antarctic Sea Ice. Proc NIPR Symp Polar Biol 9:85-91

Spindler M, Dieckmann G (1986) Distribution and abundance of the planktic foraminifer Neogloboquadrina pachyderma in sea ice of the Weddell Sea (Antarctica). Polar Biol 5:185-191. https://doi. org/10.1007/BF00441699

Tang J, Köhler SJ, Dietzel M (2008) $\mathrm{Sr}^{2+} / \mathrm{Ca}^{2+}$ and ${ }^{44} \mathrm{Ca} /{ }^{40} \mathrm{Ca}$ fractionation during inorganic calcite formation: I. Sr incorporation. Geochim Cosmochim Acta 72:3718-3732. https://doi.org/10. 1016/j.gca.2008.05.031 
Tison JL, Haas C, Gowing MM, Sleewaegen S, Bernard A (2002) Tank study of physico-chemical controls on gas content and composition during growth of young sea ice. J Glaciol 48:177-190. https://doi. org/10.3189/172756502781831377

Tison J-L, Worby A, Delille B, Brabant F, Papadimitriou S, Thomas D, de Jong J, Lannuzel D, Haas C (2008) Temporal evolution of decaying summer first-year sea ice in the Western Weddell Sea, Antarctica. Deep Sea Res Part II Top Stud Oceanogr 55:975-987. https://doi.org/10.1016/j.dsr2.2007.12.021

Tolderlund DS, Bé AWH (1971) Seasonal distribution of planktonic Foraminifera in the Western North Atlantic. Micropaleontology 17:297-329. https://doi.org/10.2307/1485143

Toyofuku T, Matsuo MY, De Nooijer LJ et al (2017) Proton pumping accompanies calcification in foraminifera. Nat Commun 8:1-6. https://doi.org/10.1038/ncomms 14145

Wit JC, De Nooijer LJ, Wolthers M, Reichart GJ (2013) A novel salinity proxy based on $\mathrm{Na}$ incorporation into foraminiferal calcite.
Biogeosciences 10:6375-6387. https://doi.org/10.5194/bg-106375-2013

Yoshimura T, Tamenori Y, Suzuki A, Kawahata H, Iwasaki N, Hasegawa H, Nguyen LT, Kuroyanagi A, Yamazaki T, Kuroda J, Ohkouchi N (2017) Altervalent substitution of sodium for calcium in biogenic calcite and aragonite. Geochim Cosmochim Acta 202:21-38. https://doi.org/10.1016/j.gca.2016.12.003

Zweng MM, Reagan JR, Antonov JI, Locarnini RA, Mishonov AV, Boyer TP, Garcia HE, Baranova OK, Johnson DR, Seidov D, Biddle MM (2013) World Ocean Atlas 2013, Volume 2: Salinity. Levitus S (ed), Mishonov A (technical ed), NOAA Atlas NESDIS $74: 39$

Publisher's note Springer Nature remains neutral with regard to jurisdictional claims in published maps and institutional affiliations. 